\title{
Phenotype, functions and fate of adoptively transferred tumor draining lymphocytes activated ex vivo in mice with an aggressive weakly immunogenic mammary carcinoma
}

\author{
Catriona HT Miller ${ }^{1}$, Laura Graham², Harry D Bear ${ }^{1,2^{*}}$
}

\begin{abstract}
Background: Regression of established tumors can be induced by adoptive immunotherapy with tumor draining lymph node lymphocytes activated with bryostatin and ionomycin. We hypothesized that tumor regression is mediated by a subset of the transferred T lymphocytes, which selectively infiltrate the tumor draining lymph nodes and proliferate in vivo.

Results: Adoptive transfer of B/I activated tumor draining lymphocytes induces regression of advanced 4T1 tumors, and depletion of CD8, but not CD4 T cells, abrogated tumor regression in mice. The predominant mediators of tumor regression are $\mathrm{CD} 8+$ and derived from $\mathrm{CD}_{2} \mathrm{~L}^{-} \mathrm{T}$ cells. Transferred lymphocytes reached their peak concentration (10.5\%) in the spleen 3 days after adoptive transfer and then rapidly declined. Adoptively transferred cells preferentially migrated to and/or proliferated in the tumor draining lymph nodes, peaking at day 5 (10.3\%) and remained up to day 28. CFSE-stained cells were seen in tumors, also peaking at day 5 (2.1\%). Bryostatin and ionomycin-activated cells proliferated vigorously in vivo, with 10 generations evident in the tumor draining lymph nodes on day 3. CFSE-stained cells found in the tumor draining lymph nodes on day 3 were $30 \% \mathrm{CD} 8^{+}, 72 \% \mathrm{CD} 4^{+}$, $95 \% \mathrm{CD}_{4} 4^{+}$, and $39 \% \mathrm{CD} 9^{+}$. Pre-treatment of recipient mice with cyclophosphamide dramatically increased the number of interferon-gamma producing cells.

Conclusions: Adoptively transferred CD8+ CD62 $\mathrm{L}^{\text {low }} \mathrm{T}$ cells are the principal mediators of tumor regression, and host $T$ cells are not required. These cells infiltrate $4 \mathrm{~T} 1$ tumors, track preferentially to tumor draining lymph nodes, have an activated phenotype, and proliferate in vivo. Cyclophosphamide pre-treatment augments the anti-tumor effect by increasing the proliferation of interferon-gamma producing cells in the adoptive host.
\end{abstract}

\section{Background}

Conventional therapies for cancer, including surgery, radiation and chemotherapeutic agents, are often ineffective at controlling the growth and spread of tumors. The immune system can potentially eliminate cancerous cells, as demonstrated by studies of numerous animal models and a few clinical trials [1,2]. In most cases, it is thought that anti-tumor effects are mediated by cytotoxic $\mathrm{T}$ lymphocytes (CTL), which recognize MHC class I-peptide complexes on the tumor cell surface [3]. Monoclonal

\footnotetext{
* Correspondence: hdbear@vcu.edu

'Department of Microbiology and Immunology, Virginia Commonwealth

University's Medical College of Virginia, Richmond, Virginia, USA

Full list of author information is available at the end of the article
}

antibodies, cytokines, and pharmacological methods have been used successfully in mouse models to activate lymphocytes isolated from tumors or tumor draining lymph nodes (DLN), which can then be adoptively transferred to tumor bearing hosts and cause regression of established tumors [4-15]. Adoptive immunotherapy (AIT), or the adoptive transfer of antigen-sensitized $T$ cells activated and/or expanded in vitro continues to receive attention [10] [16-23].

We have shown that in vitro treatment with bryostatin and ionomycin (B/I) selectively activates antigen-sensitized tumor draining lymph node (tDLN) lymphocytes [19-22]. Bryostatin 1 is a macrocyclic lactone derived from Bugula neritina, a marine invertebrate. Bryostatin activates protein 
kinase C [23-26] and ionomycin increases intracellular calcium [27]. Together, these mimic signaling through the CD3/TcR complex and lead to activation and proliferation of T cells [24,27].

Previous research in our lab has shown that adoptive transfer of B/I activated tumor draining lymphocytes can cure subcutaneous tumors and visceral metastases in murine hosts and establish long-term immunity, without evidence of autoimmunity. In the 4T1 mammary carcinoma model, we have shown that B/I selectively activates $\mathrm{CD}^{2} 2 \mathrm{~L}^{-}$or sensitized $\mathrm{T}$ cells and that the anti-tumor activity resides in the $\mathrm{CD}^{2} 2 \mathrm{~L}^{-}$fraction of lymphocytes obtained from donor lymph nodes; only the $\mathrm{CD}^{2} 2 \mathrm{~L}^{-}$subset proliferates after $\mathrm{B} / \mathrm{I}$ activation and has anti-tumor activity [28]. CD62L or L-selectin is an adhesion molecule important in $\mathrm{T}$ cell homing to lymph nodes and is down-regulated after $\mathrm{T}$ cells are activated and differentiate into their effector or effector memory $\left(\mathrm{T}_{\mathrm{EM}}\right)$ phenotypes $[29,30]$. Thus, because of this selective activation of antigen-sensitized $\mathrm{T}$ cells from the vaccinated donor mice, B/I stimulated DLN lymphocytes have tumor antigen specific activity in vivo, despite the non-specific stimulus used to promote their growth.

We hypothesized that $\mathrm{B} / \mathrm{I}$ activated $\mathrm{T}$ cells mediate tumor regression primarily by $\mathrm{CD}^{+} \mathrm{T}$ cell mediated functions and may establish $\mathrm{T}$ cell memory in the adoptive host by proliferating in vivo. B/I activated cells were characterized prior to adoptive transfer, and the most active subsets of cells identified by depletion or separation of phenotypically distinct subsets of $\mathrm{T}$ cells prior to AIT. By AIT using CFSE-labeled cells, we were also able to determine the trafficking patterns and measure the in vivo proliferation of $\mathrm{B} / \mathrm{I}$-activated $\mathrm{T}$ cells in tumorbearing hosts.

\section{Methods}

Mice

Virus-free BALB/c mice (Charles River Laboratories, Cambridge, MA) were used between 8 and 12 weeks of age, caged in groups of 6 or fewer, and provided food and water ad libitum. Nude athymic BALB/c mice (National Cancer Institute, Bethesda, MD) were used to produce hybridoma ascites. All guidelines of the Virginia Commonwealth University Institutional Animal Care and Use Committee, which conform to the American Association for Accreditation of Laboratory Animal Care and the U.S. Department of Agriculture recommendations for the care and humane experimental use of animals, were followed.

\section{Tumor cell lines and Hybridomas}

4T1 mammary tumor cell line was kindly provided by Dr. Jane Tsai at the Michigan Cancer Foundation,
Detroit, Michigan. Cells were maintained in Dulbecco's Modified Essential Medium (DMEM) with 10\% heatinactivated fetal calf serum (Hyclone, Logan, UT), $1 \mathrm{mM}$ sodium pyruvate, $100 \mathrm{U} / \mathrm{ml}$ penicillin and $100 \mu \mathrm{g} / \mathrm{ml}$ streptomycin (Sigma, St. Louis MO) (modified DMEM). Meth A sarcoma, an unrelated tumor cell line (ATCC, Rockville, MD) was maintained in RPMI 1640 medium with $10 \%$ heat-inactivated FCS, $1 \mathrm{mM}$ sodium pyruvate, $0.1 \mathrm{mM}$ nonessential amino acids, $2 \mathrm{mM}$ L-glutamine, $100 \mathrm{U} / \mathrm{ml}$ penicillin, $100 \mu \mathrm{g} / \mathrm{ml}$ streptomycin, $10 \mathrm{mM}$ Hepes buffer, and $5 \times 10^{-5} \mathrm{M} 2$-mercaptoethanol (Sigma). Tumor cells were harvested for inoculation of mice with $0.05 \%$ trypsin-EDTA (Fisher, Pittsburgh, PA). Hybridomas (GK1.5 (anti-CD4), 2.43 (anti-CD8)) were obtained from ATCC and grown in complete RPMI. All cells were incubated in $250 \mathrm{ml}$ T-flasks (PGC, Gaithersburg, $\mathrm{MD}$ ) at $37^{\circ} \mathrm{C}$ in humidified air with $5 \% \mathrm{CO}_{2}$.

\section{Monoclonal Antibody production}

Anti-CD4 monoclonal antibody (mAb) and anti-CD8 $\mathrm{mAb}$ were produced as ascites fluid from pristaneprimed nude mice injected with their respective hybridomas.

\section{Draining lymph node sensitization}

Donor mice were vaccinated in the left hind footpad with $1 \times 10^{6} 4 \mathrm{~T} 1$ cells. Ten days after footpad vaccination, popliteal tumor draining lymph nodes ( $\mathrm{tDLN}$ ) were harvested under sterile conditions.

\section{Lymphocyte activation and in vitro expansion}

DLN's were harvested and dispersed into a single cell suspension in complete RPMI media at $1 \times 10^{6}$ cells $/ \mathrm{ml}$. The cells were activated by incubation with $5 \mathrm{nM}$ bryostatin 1 (provided by the National Cancer Institute, Bethesda, MD) and $10 \mathrm{nM}$ ionomycin (Calbiochem, San Diego, CA) (B/I), and $80 \mathrm{U} / \mathrm{ml}$ of rIL-2 (Chiron, Emeryville, CA) at $37^{\circ} \mathrm{C}$ for 18 hours. Cells were washed three times with warm complete RPMI and resuspended at $1-2 \times 10^{6}$ cells $/ \mathrm{ml}$ with 40 $\mathrm{U} / \mathrm{ml}$ of rIL-2. The cells were allowed to proliferate in culture for an additional 7 days and were split every 2-3 days in order to maintain $1-2 \times 10^{6}$ cells/ml concentration.

\section{Adoptive immunotherapy}

Host mice were inoculated in the left flank with $2.5 \times$ $10^{4}-5 \times 10^{4} 4 \mathrm{~T} 1$ cells $\left(2.5 \times 10^{4}\right.$ for $7-10$ day tumors, $5 \times 10^{4}$ for 4 day tumors). One day prior to AIT, mice were pretreated with cyclophosphamide (CYP),100 mg/ kg IP(Mead Johnson, Princeton, NJ). On day 4, 7 or 10, the $\mathrm{B} / \mathrm{I}$ activated and expanded DLN lymphocytes were washed twice in serum free medium (RPMI 1640) and injected intravenously (IV) in $0.5 \mathrm{ml}$ into host mice. No systemic cytokines were administered. 


\section{CFSE staining and analysis}

Prior to adoptive immunotherapy, B/I activated DLN lymphocytes were stained with $50 \mu \mathrm{M}$ CFDA-SE (Molecular Probes, Eugene, OR) in PBS at a concentration of 75 million cells $/ \mathrm{ml}$ for 15 minutes. Cells were washed with warm media and incubated at $37^{\circ} \mathrm{C}$ for 30 minutes to allow processing by intracellular proteases. CFSEstained lymphocytes were injected IV into CYP-treated or untreated mice bearing $4 \mathrm{~T} 1$ tumors.

\section{Flow cytometry}

Cells isolated from spleen, tumor, inguinal tDLN, and cLN of control or treated mice at various time points were stained with a panel of antibodies and analyzed by dual color flow cytometry for CFSE and surface marker expression on an ELITE Beckman Coulter flow cytometer. Fluorescently labeled Abs directed against the following markers were obtained from Pharmingen (San Diego, CA): Pan-DX5(DX5), CD4 (GK1.5), CD8 (53-6.7), CD44 (IM7), CD62L (MEL-14), and CD69 (H1.2F3). Appropriate isotype controls were used in all cases. Generations of proliferation detected by CFSE fluorescence were analyzed using ModFit LT (Verity Software House, Topsham, Maine) and acceptable fits were determined by reduced Chi-Squared values.

\section{In vitro T cell subset depletion experiments}

For in vitro depletion studies, DLN were first incubated with antibody (1:100) for 30 minutes, washed, and then incubated with rabbit complement $\left(C^{\prime}\right)$ (Accurate Chemical) at $37^{\circ} \mathrm{C}$ for 30 minutes. The efficacy of the depletion was tested by flow cytometry. To determine the CD62L phenotype of the sensitized $\mathrm{T}$ cell precursors that were activated by $\mathrm{B} / \mathrm{I}$ to become anti-tumor effectors or of the cells after B/I activation that mediated anti-tumor effects in adoptive hosts, DLN cells before and/or after activation with $\mathrm{B} / \mathrm{I}$ were separated into $\mathrm{CD} 62 \mathrm{~L}^{-}$and $\mathrm{CD} 62 \mathrm{~L}^{+}$subsets using magnetic bead separation (EasySep, Stem Cell Technologies). Flow cytometry was used to verify fractionation.

\section{Tumor measurements}

In all AIT experiments, tumor growth was monitored with biweekly measurements of perpendicular diameters. Results are reported as the mean tumor area \pm standard error (SE). When the tumor area was greater than 100 $\mathrm{mm}^{2}$ or if a mouse appeared ill, the animal was euthanized by $\mathrm{CO}_{2}$ inhalation. Complete tumor regression was defined as the absence of a measurable tumor on three consecutive measurements.

\section{Cytokine release assays}

Interferon- $\gamma($ IFN- $\gamma$ ) release from tumor sensitized, fresh or $\mathrm{B} / \mathrm{I}$ activated and expanded lymphocytes in response to stimulation with irradiated $4 \mathrm{~T} 1$ and irradiated Meth A for 24 hours was assayed using ELIspot assays from Pharmingen (San Diego, CA).

\section{Statistical analysis}

Differences in tumor growth were assessed by analysis of variance (ANOVA) and Tukey-Kramer honestly significant difference test (Tukey's HSD) using JMP $\mathrm{IN}_{\mathrm{IN}}$ software (SAS Institute Inc., Cary, N.C.). In vivo experiments included at least six mice per group and were repeated at least twice. A p $<0.05$ was used throughout to determine significant differences.

\section{Results}

Adoptive transfer of tDLN activated by $B / I$ and expanded in vitro induces regression of 10 day 4T1 tumors

Host Balb/C mice with 4T1 tumors were untreated, treated with CYP on day 9, or treated with CYP followed on day 10 by adoptive transfer of B/I-activated 4T1 DLN cells. As shown in Figure 1, CYP treatment alone briefly slowed tumor progression, but did not lead to complete tumor regression in any mice. Complete tumor regression was seen in 6 out of 6 mice treated with CYP plus adoptive transfer of B/I-activated tumor-sensitized lymphocytes. We have previously shown and published that adoptive transfer of B/I activated $4 \mathrm{~T} 1 \mathrm{DLN}$ was ineffective at inducing tumor regression [28,31].

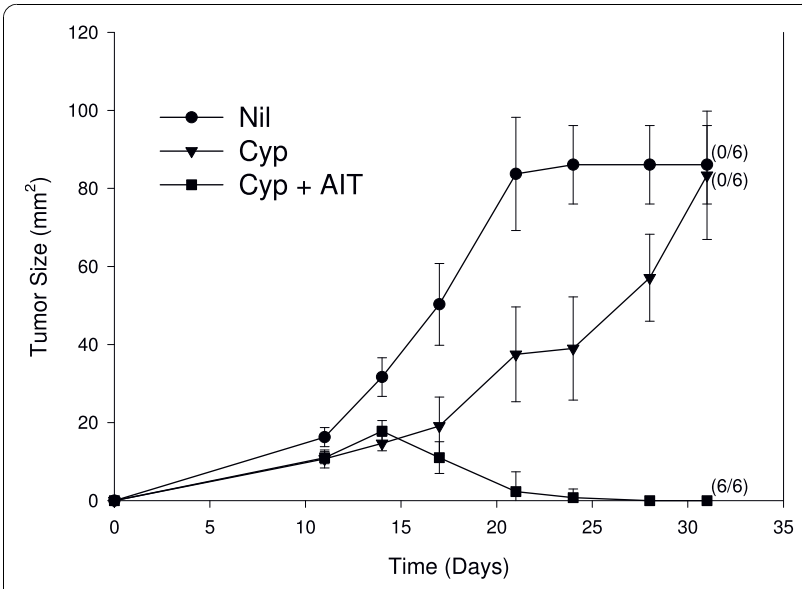

Figure 1 Adoptive transfer of bryostatin and ionomycin activated tumor DLN lymphocytes induces regression of 10 day 4T1 tumors. Mice with established 9 day tumors either were untreated or were treated with CYP (100 mg/kg i.p. on day 9), alone, or CYP followed by adoptive transfer of $10 \times 10^{6} 4 \mathrm{~T} 1 \mathrm{DLN}$ lymphocytes (on day 10) which had been activated with $B / I$ and expanded in culture. Mean tumor areas \pm SE are charted over time versus days after tumor inoculation. Treatment with CYP + B/I activated lymphocytes induced complete tumor regressions in 100\% of the mice. CYP treatment alone slowed tumor growth only temporarily. Numbers to the right indicate the number of mice with complete tumor regression per total number of mice in each group. The CYP + AIT group was significantly different from the Nil and CYP groups $[F(2,17)=21.8328, P<0.0001]$. 


\section{$\mathrm{CD8}^{+}$cells are the predominant mediators of tumor regression}

We hypothesized that the predominant cells responsible for tumor regression induced by AIT with B/I-activated tDLN cells would be in the $\mathrm{CD}^{+}$subset. By immunohistochemistry, we had previously seen $\mathrm{CD} 4^{+}$and $\mathrm{CD} 8^{+}$ $\mathrm{T}$ cells infiltrating tumors in mice treated with $\mathrm{B} / \mathrm{I}$ activated lymphocytes [28]. To determine the relative roles of CD4 and CD8 T cell subsets in inducing tumor regression, BALB/c mice bearing 4 day tumors and pre-treated with CYP, underwent AIT using untreated B/I activated DLN cells, C'-treated cells, anti-CD $4+C^{\prime}$-treated cells, or anti-CD8 + C'-treated cells. In mice treated with CD8depleted cells, 4T1 tumor growth was depressed slightly compared to CYP alone, but none of the tumors regressed completely, and tumor sizes were not significantly different from CYP alone (Figure 2). In tumorbearing mice treated with CD4-depleted DLN, 4T1

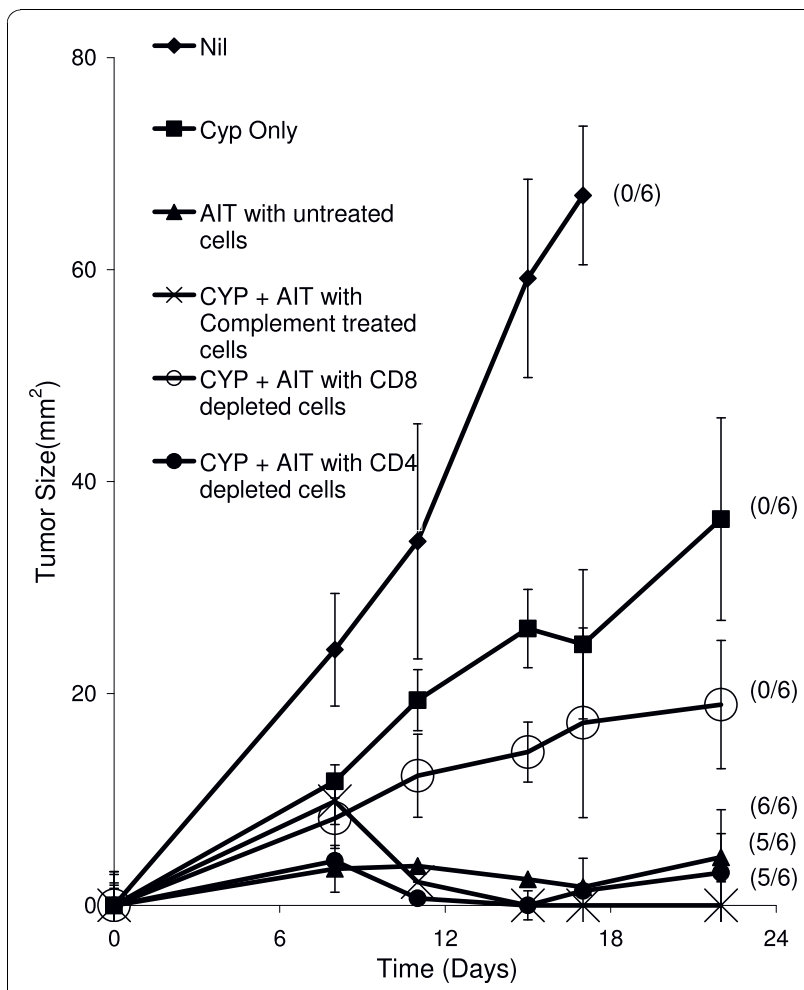

Figure 2 Therapeutic effect of AIT is mediated predominantly by $\mathrm{CDB}^{+} \mathbf{T}$ cells. Mice with established $4 \mathrm{~T} 1$ flank tumors were either untreated, treated with CYP alone (on day 3) or CYP on day 3 + AIT on day 4 with $20 \times 10^{6}$ cells from culture. The cells infused for AIT were either untreated, treated with $C^{\prime}$ alone, treated with anti-CD8 Ab + $C^{\prime}$ or with anti-CD4 antibody $+C^{\prime}$ prior to transfer. Mean tumor sizes \pm SE are charted over time. Numbers to the right indicate the number of mice with complete tumor regression per total number of mice in each group. The results with AIT using untreated, C' treated, and CD4-depleted cells were significantly different from the untreated group, the CYP only group, and the CD8-depleted AIT groups $[\mathrm{F}(4,24)=32.45, \mathrm{P}<0.0001]$. tumors regressed completely in 5/6 mice, with a growth curve that was little different from AIT with untreated or C'-treated cells.

\section{Host T cells are not required for tumor regression}

To confirm our hypothesis that host $\mathrm{T}$ cells play little or no role in tumor regression after adoptive transfer, athymic nude mice with 4 day $4 \mathrm{~T} 1$ tumors were treated with CYP alone or CYP + B/I activated 4T1 draining lymphocytes, with or without exogenous IL-2 (7500 U i.p. on days 0 - 3 after AIT). Adoptive transfer of B/I activated tDLN was effective at inducing $4 \mathrm{~T} 1$ tumor regression in nude mice pre-treated with CYP but IL-2 was neither beneficial nor required(data not shown, $[F(2,13)=11.289, \mathrm{P}=0.0014])$. This result indicates that host $\mathrm{T}$ cells are neither required for tumor regression.

\section{$B / I$ activated tDLN demonstrate increased expression of message for cytolytic mediators}

We hypothesized that B/I activation and in vitro expansion of tumor draining lymphocytes led to the development of highly activated effector $\mathrm{T}$ cells, capable of inducing tumor regression. Activation and expansion of tDLN lymphocytes with B/I + IL-2 was associated with increased expression of mRNA for molecules associated with cytotoxic activity, including granzyme B, perforin, and Fas ligand, when compared to unactivated tDLN (Figure 3A).

\section{$\mathrm{B} / \mathrm{I}$ activated $\mathrm{tDLN}$ release IFN- $\boldsymbol{\gamma}$ in response to tumor challenge}

We and others have previously noted a strong correlation between interferon- IFN- $\gamma$ production and tumor regression in other tumor models [31-37]. BALB/c mice were either untreated, vaccinated with irradiated $4 \mathrm{~T} 1$, treated with CYP alone, or treated with CYP + AIT with B/I activated 4T1 tDLN lymphocytes. Spleens were harvested 5 days after adoptive transfer, and pooled splenocytes from 3 mice in each treatment group were co-cultured with irradiated 4T1 or unrelated MethA sarcoma for 24 hours on an IFN- $\gamma$ ELISpot plate. As shown in Figure $3 \mathrm{~b}$, numbers of IFN- $\boldsymbol{\gamma}$ producing cells were greatest in response to $4 \mathrm{~T} 1$ in mice treated with CYP + AIT. A small number of cells in each of the other groups also produced IFN- $\boldsymbol{\gamma}$ in response to 4T1, which may be explained by sensitization to $4 \mathrm{~T} 1$ in these tumor-bearing hosts. There was no IFN- $\boldsymbol{\gamma}$ response to Meth A.

$B / I$ activation leads to increased expression of memory markers by tumor draining lymphocytes

There have recently been reports in the literature that adoptive transfer of central memory or early effector phenotype cells (which are CD62 $\mathrm{L}^{\text {high }}$ ) is more effective 


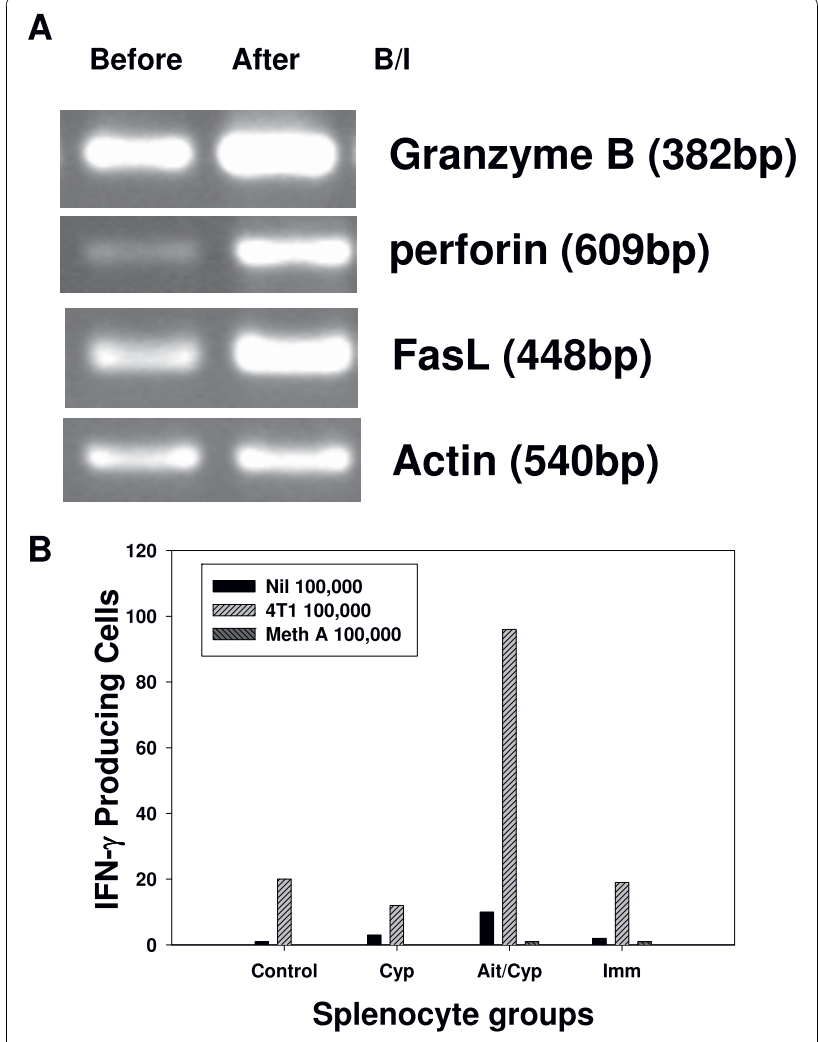

Figure 3 Adoptive transfer of B/I activated T cells into CYP pretreated hosts results in tumor specific production of interferon- $\boldsymbol{\gamma}$ and other cytotoxic mediators by adoptive host splenocytes. A) RT-PCR analysis of granzyme B, perforin, FasL and actin mRNA from murine 4T1 tumor-DLN CD8 ${ }^{+}$cells, either fresh or after activation with $\mathrm{B} / \mathrm{I}$ and expansion in IL-2. Increased expression of FasL, perforin, and granzyme B was seen in CD8+ T cells after B/I activation. This is a representative experiment of 3 replicates. B) ELIspot assays for IFN- $\gamma$ producing cells from spleens of untreated 4T1 tumor-bearing mice, CYP-treated tumor-bearing mice, tumor bearing mice treated with CYP + AIT with B/l-activated tDLN, and 4T1 bearing mice immunized with irradiated 4T1 cells. Splenocytes were unstimulated or stimulated in vitro with 4T1 or Meth A sarcoma cells. Results are shown for pooled spleens from 3 mice in each group. Mean values from paired wells are shown. This is a representative experiment of 5 replicates.

against tumor than adoptive transfer of effector memory or late effector phenotype (CD62 $\left.\mathrm{L}^{\text {low }}\right) \mathrm{T}$ cells $[38,39]$. Over the course of expansion after B/I activation, we observed upregulation of CD62L by previously CD62 $\mathrm{L}^{-}$ cells; $70 \%$ of the adoptively transferred cells in the B/Iactivated cultured tDLN cells were CD62 $\mathrm{L}^{+}$. In addition, we have previously observed in $\mathrm{B} / \mathrm{I}$ activated cells minimal levels of cytotoxic activity and high IFN- $\gamma$ production, which are also consistent with a central memory/ early effector phenotype. Therefore, we investigated the hypothesis that activation with $\mathrm{B} / \mathrm{I}$ could skew the phenotype of activated $\mathrm{T}$ cells towards a central memory or early effector phenotype, and that these cells were largely responsible for their anti-tumor efficacy.

In Table 1, expression of phenotypic markers of memory $\mathrm{T}$ cells before and after $\mathrm{B} / \mathrm{I}$ activation is shown for the fraction of tDLN cells that were initially CD62 $\mathrm{L}^{-}$. 4T1 tDLN were separated into their CD62L subsets by magnetic bead selection. Prior to B/I activation, the $\mathrm{CD}^{2} 2 \mathrm{~L}^{-}$fraction was $93 \% \mathrm{CD}^{2} 2 \mathrm{~L}^{-}$overall and $81 \%$ of the CD8 cells in that fraction were CD62L- After B/I activation and expansion, expression of CD62L, CD127, CD69, and CD27 increased dramatically. These increases in expression of CD127, CD27, CD69, and CD62L are consistent with acquisition of a central memory $\left(\mathrm{T}_{\mathrm{CM}}\right)$ phenotype, but we did not observe significant upregulation of CCR7, another memory marker.

Before and after B/l activation and expansion, anti-tumor activity resides predominantly in the $\mathrm{CD}^{2} \mathrm{~L}^{-}$subset To test the hypothesis that $\mathrm{T}_{\mathrm{CM}}$ cells (which should be $\mathrm{CD} 2 \mathrm{~L}^{+}$) generated after $\mathrm{B} / \mathrm{I}$ activation are responsible for the efficacy of these cells at inducing tumor regression, we separated B/I activated and expanded 4T1 tDLN into $\mathrm{CD}^{2} \mathrm{~L}^{+}$and $\mathrm{CD} 62 \mathrm{~L}^{-}$fractions, using magnetic beads. Unsorted, CD62 $\mathrm{L}^{+}$, and CD62 $\mathrm{L}^{-}$cells were then infused into CYP pre-treated 4T1 tumor bearing mice (Figure 4). Surprisingly, the $\mathrm{CD}^{2} 2 \mathrm{~L}^{+}$subset did not induce tumor regression, while the CD62 $\mathrm{L}^{-}$subset was highly effective.

To characterize not only the ultimate phenotype of antitumor effectors after B/I activation, but also the origin of the adoptively transferred cells that mediate the antitumor activity, we separated tDLN into $\mathrm{CD}^{2} 2 \mathrm{~L}^{+}$and $\mathrm{CD}^{2} \mathrm{~L}^{-}$fractions, both before and after B/I stimulation and expansion. Unsorted B/I activated lymphocytes, $\mathrm{CD}_{2} \mathrm{~L}^{+}$cells that remained $\mathrm{CD} 62 \mathrm{~L}^{+}$after B/I and expansion $\left(\mathrm{CD} 6 \mathrm{~L}^{+} \rightarrow \mathrm{CD} 2 \mathrm{~L}^{+}\right), \mathrm{CD} 6 \mathrm{~L}^{+}$cells that downregulated $\mathrm{CD} 62 \mathrm{~L}$ after $\mathrm{B} / \mathrm{I}$ treatment and expansion $\left(\mathrm{CD} 62 \mathrm{~L}^{+}\right.$ $\rightarrow \mathrm{CD} 2 \mathrm{~L}^{-}$), CD62L- cells that remained CD62L- after B/I

Table 1 Phenotype of CD62L-enriched T cells from tDLN, before and after $B / I$ pulse and expansion in IL-2

\begin{tabular}{ccc}
\hline \% of CD8 cells which express: & Before B/I & After B/I \\
\hline CD62 $^{+}$ & $19 \%$ & $46 \%$ \\
CD127 $^{+}$ & $9 \%$ & $48 \%$ \\
CD69 $^{+}$ & $45 \%$ & $90 \%$ \\
CD27 $^{+}$ & $37 \%$ & $89 \%$ \\
CCR7 $^{+}$ & $46 \%$ & $42 \%$ \\
\hline
\end{tabular}

4T1 tDLN were harvested and separated by expression of CD62L. Subsets were activated by $\mathrm{B} / \mathrm{I}$ and expanded for 7 days. Prior to $\mathrm{B} / \mathrm{I}$ activation, and again after expansion, cells were stained for expression of CD8, CD62L, CD127, CD69, CD27, and CCR7. The CD62L' fraction was initially 93\% CD62L- overall. Shown in the table is the percentage of $\mathrm{CD} 8^{+}$cells which express specific $\mathrm{T}$ cell markers, before and after B/l expansion, in the initially $\mathrm{CD}_{2} \mathrm{~L}^{-}$fraction of tDLN cells. Results are representative of more than three independent experiments. 


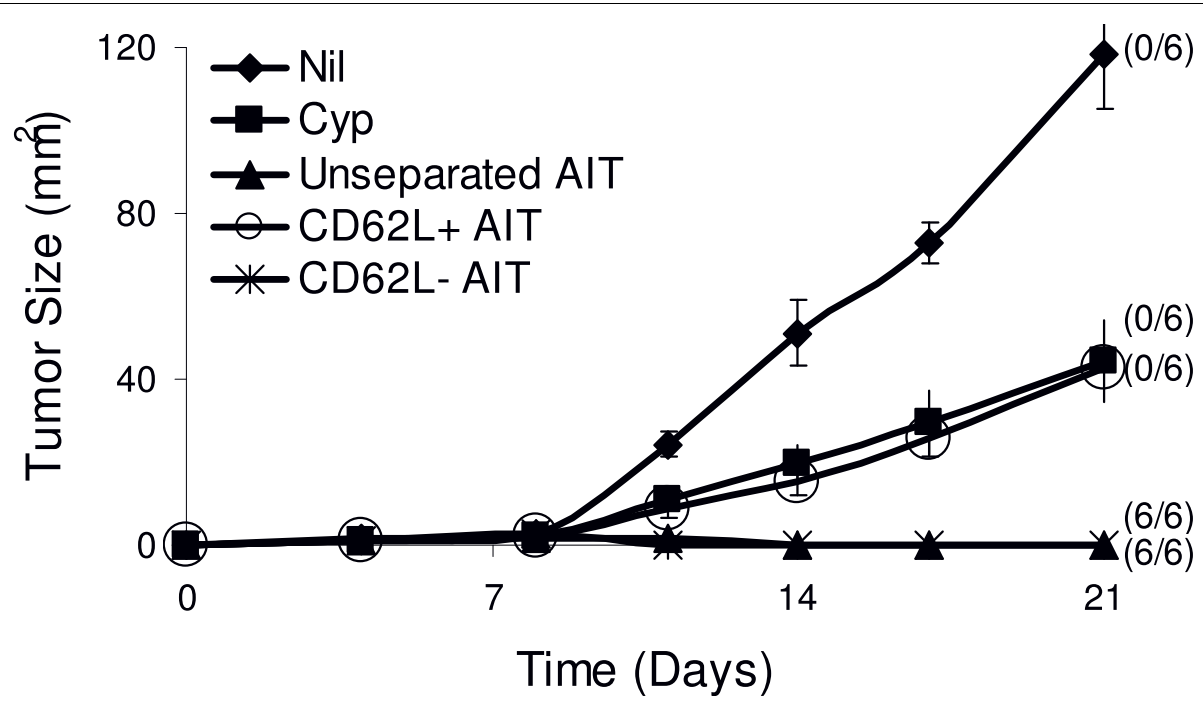

Figure $4 \mathrm{CD} 62 \mathrm{~L}$ phenotype (after B/I activation and expansion) of T cells mediating tumor regression. Mice with established 4T1 flank tumors were either untreated, treated with CYP alone $\left(100 \mathrm{mg} / \mathrm{kg}\right.$ i.p. on day 3) or CYP + AIT (on day 4) with $10 \times 10^{6}$ unsorted, CD62L $^{+}$or CD62 $\mathrm{B} /$ / activated tumor-sensitized lymphocytes. CD62L separation was performed after B/I activation and expansion for 7 days in culture, just prior to adoptive transfer. Mean tumor sizes \pm SE are charted over time. Numbers to the right indicate the number of mice with complete tumor regression per total number of mice in each group. The AIT and CD62 $\mathrm{L}^{-}$AIT groups were significantly different from the untreated group and the $\mathrm{CD}_{2} \mathrm{~L}^{+}$AlT groups $[\mathrm{F}(4,29)=15.3889, \mathrm{P}<0.0001]$.

treatment and expansion $\left(\mathrm{CD} 6 \mathrm{~L}^{-} \rightarrow \mathrm{CD}^{-} 2 \mathrm{~L}^{-}\right)$, or CD62L cells that upregulated $\mathrm{CD} 62 \mathrm{~L}$ expression after $\mathrm{B} / \mathrm{I}$ and expansion $\left(\mathrm{CD} 62 \mathrm{~L}^{-} \rightarrow \mathrm{CD} 6 \mathrm{~L}^{+}\right)$were infused into CYP pre-treated tumor bearing mice (Figure 5). Prior to $\mathrm{B} / \mathrm{I}$ activation, between $75-83 \%$ of lymphocytes are CD62 $\mathrm{L}^{+}$ and $17-25 \%$ are $\mathrm{CD}_{62} \mathrm{~L}^{-}$(pooled data from 4 experiments). After $\mathrm{B} / \mathrm{I}$ activation, from the initially $\mathrm{CD} 62 \mathrm{~L}^{+}$fraction, $87 \%$ of the cells remained $\mathrm{CD}^{2} 2 \mathrm{~L}^{+}$and $13 \%$ downregulated CD62L. From the initially CD62 $\mathrm{L}^{-}$fraction, $80 \%$ of the cells remained $\mathrm{CD}^{2} 2 \mathrm{~L}^{-}$and $20 \%$ of the cells upregulated CD62L (Representative data from one experiment of 4). In 4 out of 4 experiments, CD62 $\mathrm{L}^{-} \rightarrow \mathrm{CD}^{2} 2 \mathrm{~L}^{-}$cells induced complete tumor regression, even when as few as 375,000 cells per mouse were transferred (Figure 5a, 5b). In 3 out of 4 experiments, CD62 $\mathrm{L}^{-} \rightarrow \mathrm{CD} 6 \mathrm{~L}^{+}$cells induced complete tumor regression(Figure $5 \mathrm{a}$ ). However, when $\mathrm{B} / \mathrm{I}$ activated lymphocyte subsets were used to treat slightly larger tumors (inoculated at 100,000 cells/mouse, $2 x$ the usual inoculum), CD62L $\rightarrow \mathrm{CD}^{-} 2 \mathrm{~L}^{+}$cells were not effective at mediating tumor regression, slowing tumor growth only slightly (Figure $5 \mathrm{~b}$ ). In contrast, even with the greater tumor burden, CD62 $\mathrm{L}^{-} \rightarrow \mathrm{CD} 6 \mathrm{~L}^{-}$cells induced complete tumor regression in all of the treated mice (Figure 5b). In all experiments, CD62 $\mathrm{L}^{+} \rightarrow \mathrm{CD}^{2} 2 \mathrm{~L}^{-}$cells were incapable of mediating tumor regressions, but with smaller tumor burdens these cells did delay tumor growth modestly (Figure 5a). Finally, adoptive transfer of CD62L ${ }^{+}$ $\rightarrow \mathrm{CD} 2 \mathrm{~L}^{+}$cells was consistently ineffective at inhibiting tumor growth (Figure 5).
Adoptively transferred cells persist in the tumor-bearing host, accumulating preferentially in the tumor draining lymph nodes

By staining B/I activated DLN lymphocytes with CFSE prior to adoptive transfer, the cells can be "tracked," and proliferation of the adoptively transferred cells can also be measured in the host. At 1 hour, 3, 5, 7, and 12 days after adoptive transfer, we harvested the spleens, lungs, inguinal tDLN, and contralateral lymph node (cLN) from AIT-treated mice. The proportion of CFSE + cells in the spleen peaked on day 3 at 10.5\% of the total splenocytes and then declined rapidly (Table 2). Only a small proportion of $\mathrm{CFSE}^{+}$cells were found in tumors on day 3 , but increased to a maximum of $2 \%$ by day 5 ; $\mathrm{CFSE}^{+}$cell proportions declined thereafter.

CFSE + cells in tDLN were $9 \%$ of the cells by day 3 and persisted at that level at least until day 12 . CFSE ${ }^{+} \mathrm{T}$ cells were seen in the tDLN up to 28 days (2.7\%) after AIT (latest date tested, data not shown). Although, $\mathrm{CFSE}^{+}$cells were 6 to $8 \%$ of cells in the contralateral lymph node between days 3 and 12 after AIT, the total number of lymphoid cells in the cDLN was much lower than in the tDLN at all times examined. Thus, the total number of $\mathrm{CFSE}^{+}$cells in the tDLN was up to 170 -fold higher than in the cDLN (Table 3). This suggests that the increased numbers of adoptively transferred cells in the tDLN likely results from selective trafficking and/or increased proliferation. 


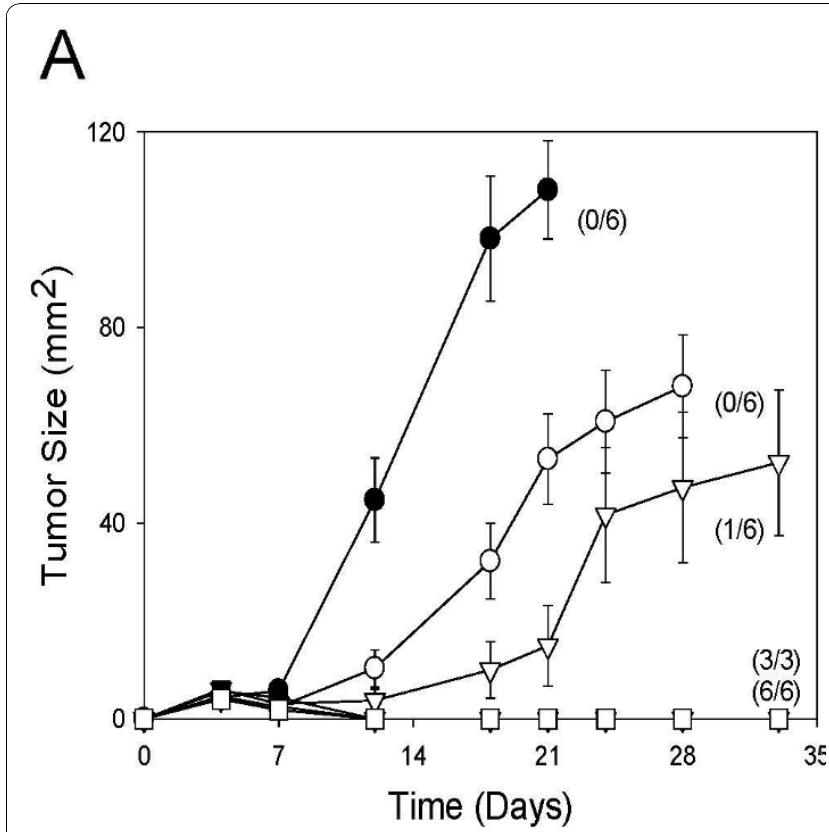

B
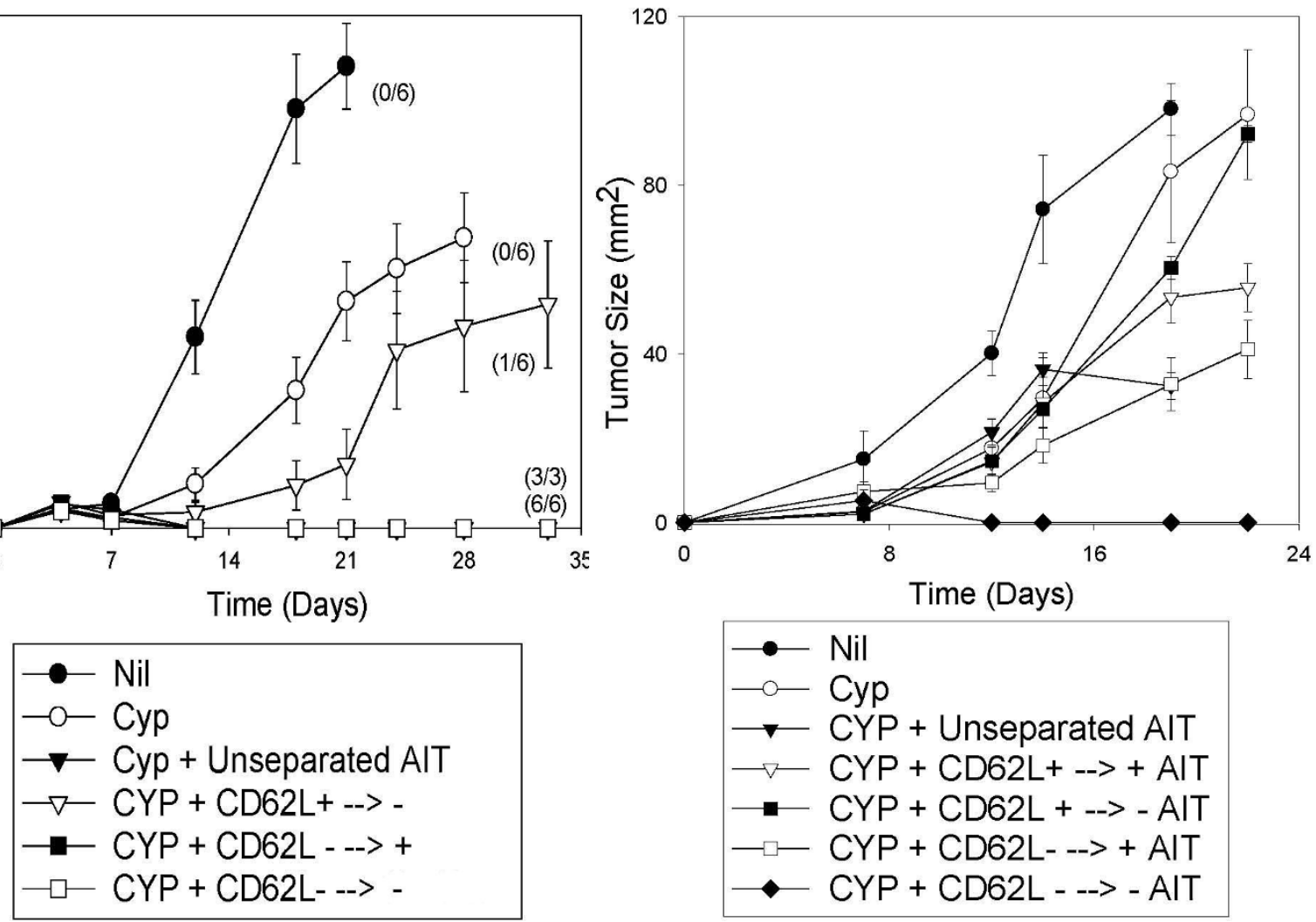

Figure 5 Anti-tumor activity resides predominantly in the subset of tDLN cells that were initially CD62 $\mathrm{L}^{-}$and remained CD62 $\mathrm{L}^{-}$after $\mathrm{B} /$ I activation and expansion in culture. Tumor-sensitized lymphocytes were separated by CD62L phenotype, both before and after B/I activation, resulting in 5 groups: unsorted B/l activated $t D L N, C D 62 L^{+}$cells that remained $C D 62 L^{+}$after $B /$ /l activation and expansion $\left(C D 62 L^{+} \rightarrow\right.$

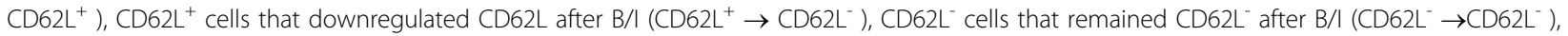
and $\mathrm{CD}_{22} \mathrm{~L}^{-}$cells that upregulated $\mathrm{CD} 62 \mathrm{~L}$ expression after $\mathrm{B} / \mathrm{l}\left(\mathrm{CD}_{2} \mathrm{~L}^{-} \rightarrow \mathrm{CD} 2 \mathrm{~L}^{+}\right)$. Mean tumor sizes $\pm \mathrm{SE}$ are charted over time. Numbers to the right indicate the number of mice with complete tumor regression per total number of mice. A) $4 \mathrm{~T} 1$ tumor-bearing mice (3 days after inoculation of 50,000 4T1 cells) were either untreated, treated with CYP alone or treated with CYP + AIT (on day 4) with unfractionated or twice

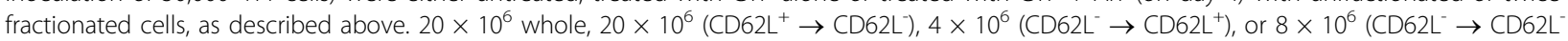
) cells were transferred, variations due to the limited number of cells available in subsets. The unseparated, (CD62 $\left.\mathrm{L}^{-} \rightarrow \mathrm{CD} 6 \mathrm{~L}^{+}\right)$, and $\left(\mathrm{CD} 6 \mathrm{~L}^{-} \rightarrow\right.$ $\mathrm{CD}^{2} \mathrm{~L}^{-}$) groups were significantly different from the untreated, CYP only, and (CD62L $\left.{ }^{+} \rightarrow \mathrm{CD}^{2} \mathrm{~L}^{-}\right)$groups $[\mathrm{F}(5,32)=22.9156, \mathrm{P}<0.0001]$. B) $4 \mathrm{~T} 1$ tumor-bearing mice (3 days after inoculation of 100,000 4T1 cells) were either untreated, treated with CYP alone or treated with CYP + AIT (on day 4) with $15 \times 10^{6}$ unfractionated or twice fractionated cells (except for the (CD62 $\mathrm{L}^{-} \rightarrow \mathrm{CD} 6 \mathrm{~L}^{+}$) group, which received $10 \times 10^{6}$ cells). The

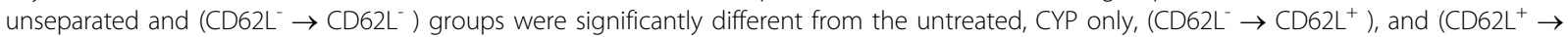
$\left.\mathrm{CD} \mathrm{L}^{-}\right)$groups $[\mathrm{F}(6,37)=17.7496, \mathrm{P}<0.0001]$

Because CFSE dilutes with cell proliferation, we also assessed $\mathrm{T}$ cell infiltration in tumors by immunohistochemistry. We observed that tumors from mice treated with AIT using vDLN cells showed infiltration of CD8+ T cells (16-50\%) on day 1 after AIT and CD8+ cells persisted at levels under $15 \%$ until the last time point checked (day 11). We did not observe infiltration of untreated or CYP treated tumors by CD $8+\mathrm{T}$ cells at any of the time points (data shown in table 4). CD4 infiltrate was seen in all tumor bearing mice, with greater percentages of CD4 infiltrate seen in AIT + CYP treated tumors, as compared to untreated or CYP treated hosts (data not shown).

\section{The trafficking and/or proliferation of adoptively} transferred cells in the host is tumor specific

To determine whether the selective accumulation of adoptively transferred cells in the lymphoid organs of adoptive hosts was antigen specific or resulted from non-specific changes caused by growth of a tumor, $\mathrm{B} / \mathrm{I}$ activated lymphocytes labeled with CFSE were infused into normal mice, 4T1-bearing hosts, and MethA 
Table 2 In vivo trafficking and accumulation over time of adoptively transferred cells in tumor-bearing mice

\begin{tabular}{lrrrr}
\hline & tDLN & cLN & Tumor & Spleen \\
\hline Day 0 & $0.7 \%$ & $0.7 \%$ & $0.1 \%$ & $3.0 \%$ \\
Day 3 & $9.2 \%$ & $5.9 \%$ & $0.2 \%$ & $10.5 \%$ \\
Day 5 & $10.1 \%$ & $7.3 \%$ & $2.1 \%$ & $3.1 \%$ \\
Day 7 & $10.3 \%$ & $6.5 \%$ & $0.8 \%$ & $3.4 \%$ \\
Day 12 & $8.4 \%$ & $8.7 \%$ & $0.1 \%$ & $2.1 \%$ \\
\hline
\end{tabular}

Mice with established 4T1 flank tumors were either untreated, treated with CYP alone on day 9, or were treated with CYP on Day 9 followed by AIT with $50 \times 10^{6}$ CFSE-stained B/I activated 4T1 tDLN (on day 10). At 1 hour, 3, 5, 7, and 12 days after AIT, the tumors, spleens, tDLN, and contralateral LN (CLN) were harvested and analyzed by flow cytometry for $\mathrm{CFSE}^{+}$cells. This is a representative experiment of 5 replicates. Percentages of CFSE ${ }^{+}$cells found in different tissues at various times after AIT (" 0 " is 1 hour after infusion of cells) are shown.

sarcoma bearing-hosts. In the absence of $4 \mathrm{~T} 1$ tumor antigen, accumulation and/or proliferation of adoptively transferred cells was greatly reduced. On day $3,10.4 \%$ of the splenocytes in $4 \mathrm{~T} 1$ bearing hosts were $\mathrm{CFSE}^{+}$, compared to only $2.1 \%$ in MethA bearing hosts and $2.4 \%$ in naïve hosts. On day $6,3.3 \%$ of the splenocytes in a $4 \mathrm{~T} 1$ bearing host were $\mathrm{CFSE}^{+}$, but only $0.5 \%$ were $\mathrm{CFSE}^{+}$in a MethA bearing host. Similar results were seen in the tDLN; $9.2 \%$ of $4 \mathrm{~T} 1 \mathrm{tDLN}$ were $\mathrm{CFSE}^{+}$on day 3 and $10.1 \%$ on day 6 . In MethA tDLN, only $3.1 \%$ of the cells were $\mathrm{CFSE}^{+}$on day 3 , declining to $2 \%$ on day 6 (data summarized in Table 5).

\section{Adoptively transferred cells have an activated phenotype} in the tumor bearing host (TBH)

In order to determine the phenotypes of the adoptively transferred cells accumulating in the recipient tDLN after AIT with $\mathrm{B} / \mathrm{I}$-activated lymphocytes, tDLN were harvested from $4 \mathrm{~T} 1 \mathrm{TBH}$ mice at varying times after CYP + AIT with CFSE-labelled B/I-activated lymphocytes. On day $3,27.6 \%$ of $\mathrm{CFSE}^{+}$cells in the tDLN were $\mathrm{CD} 8^{+}, 70.3 \%$ were $\mathrm{CD} 4^{+}$, and $0.3 \%$ were $\mathrm{DX}^{+}$(Figure 6a). More than $95 \%$ of the $\mathrm{CFSE}^{+}$cells in the tDLN were $\mathrm{CD} 44^{+}$on days 3,6 , and 10 . Between $76 \%$ and $80 \%$ of the $\mathrm{CFSE}^{+}$cells in the tDLN were $\mathrm{CD}^{2} 2 \mathrm{~L}^{+}$, and $46.5-48.6 \%$ of the adoptively transferred cells in the tDLN were $\mathrm{CD}^{+} 9^{+}$. As shown in Figure 6b, three to four

Table 3 Absolute numbers of adoptively transferred cells in lymph nodes of tumor-bearing mice

\begin{tabular}{crrrr}
\hline & Day 3 & Day 5 & Day 7 & Day 10 \\
\hline tDLN & $4.6 \times 10^{5}$ & $3.9 \times 10^{5}$ & $2.8 \times 10^{5}$ & $2.1 \times 10^{5}$ \\
CLN & $9.1 \times 10^{4}$ & $2.3 \times 10^{3}$ & $1.8 \times 10^{4}$ & $6.4 \times 10^{4}$ \\
\hline
\end{tabular}

Mice with established 4T1 flank tumors were either untreated, treated with CYP alone on day 9, or were treated with CYP on Day 9 after tumor inoculation followed by AIT with $50 \times 10^{6}$ CFSE-stained B/I activated 4T1 tDLN (on day 10). At 1 hour, 3, 5, 7, and 10 days after AIT, the tDLN and contralateral $\mathrm{LN}(\mathrm{CLN})$ were harvested and analyzed by flow cytometry for $\mathrm{CFSE}^{+}$cells. This is a representative experiment of 5 replicates. Absolute numbers of cells found in each tissue are listed.
Table 4 CD8+ $T$ cells infiltrate 4T1 tumors after AIT treatment

\begin{tabular}{rccc}
\hline Group & Nil & CD4 & CD8a \\
\hline Day 1: Control & - & + & - \\
Cyp & - & - & - \\
AIT/CYP & - & ++ & ++ \\
Day 4: Control & - & + & - \\
CYP & - & ++ & - \\
AIT/CYP & - & +++ & + \\
Day 7: Control & - & + & - \\
CYP & - & + & - \\
AIT/CYP & - & + & + \\
Day 11: Control & - & ++ & - \\
CYP & - & + & - \\
AIT/CYP & - & +++ & + \\
\hline
\end{tabular}

\section{Grading:}

- No stain

$+1-15 \%$

$++16-50 \%$

$+++>50 \%$

Mice with established 4T1 flank tumors were either untreated, treated with CYP alone on day 3, or were treated with CYP on Day 3 after tumor inoculation followed by AIT with $25 \times 10^{6} \mathrm{~B} / \mathrm{l}$ activated 4T1 tDLN (on day 4). At 1, 4, 7 and 11 days after AIT, the tumors were harvested and tumor crosssections were stained for CD4 and CD8 expression. A representative experiment is shown.

distinct generations of $\mathrm{CFSE}^{+}$cells became evident as time progressed.

Adoptively transferred cells proliferate in the tumor bearing host, with more generations seen in the tumor draining lymph nodes than in the contrateral nodes With the use of Modfit analysis software, it is possible to determine the number of cycles of proliferation occurring in CFSE labeled cells, and the percentage of cells in each generation. As shown in Figure 7, greater proliferation of the adoptively transferred cells was seen in tDLN, with higher percentages of cells in later generations than in cLN on days 3 and 6 after adoptive transfer. On day $3,30.42 \%$ of the adoptively transferred cells in tDLN were in generations 5 and above, compared to just $19.74 \%$ of cells in the cLN. The difference

Table $5 \mathrm{~B} / \mathrm{l}$ activated tDLN track preferentially to $4 \mathrm{T1}$ tDLN and persist

\begin{tabular}{ccccc}
\hline Tumor & & MethA & 4T1 & No Tumor \\
\hline Day 3 & Spleen & $2.1 \%$ & $10.4 \%$ & $2.4 \%$ \\
Day 6 & Spleen & $0.5 \%$ & $3.3 \%$ & $1.7 \%$ \\
Day 3 & tDLN & $3.1 \%$ & $9.2 \%$ & - \\
Day 6 & tDLN & $2 \%$ & $10.1 \%$ & - \\
\hline
\end{tabular}

Naïve mice or mice with established MethA or 4T1 flank tumors were treated with CYP on day 9 followed by AIT with $50 \times 10^{6}$ CFSE-stained B/I activated $4 \mathrm{~T} 1$ tDLN (on day 10). At 3 and 6 days after AIT, the tDLN and spleens were harvested and analyzed by flow cytometry for CFSE + cells. This is a representative experiment of 3 replicates. 


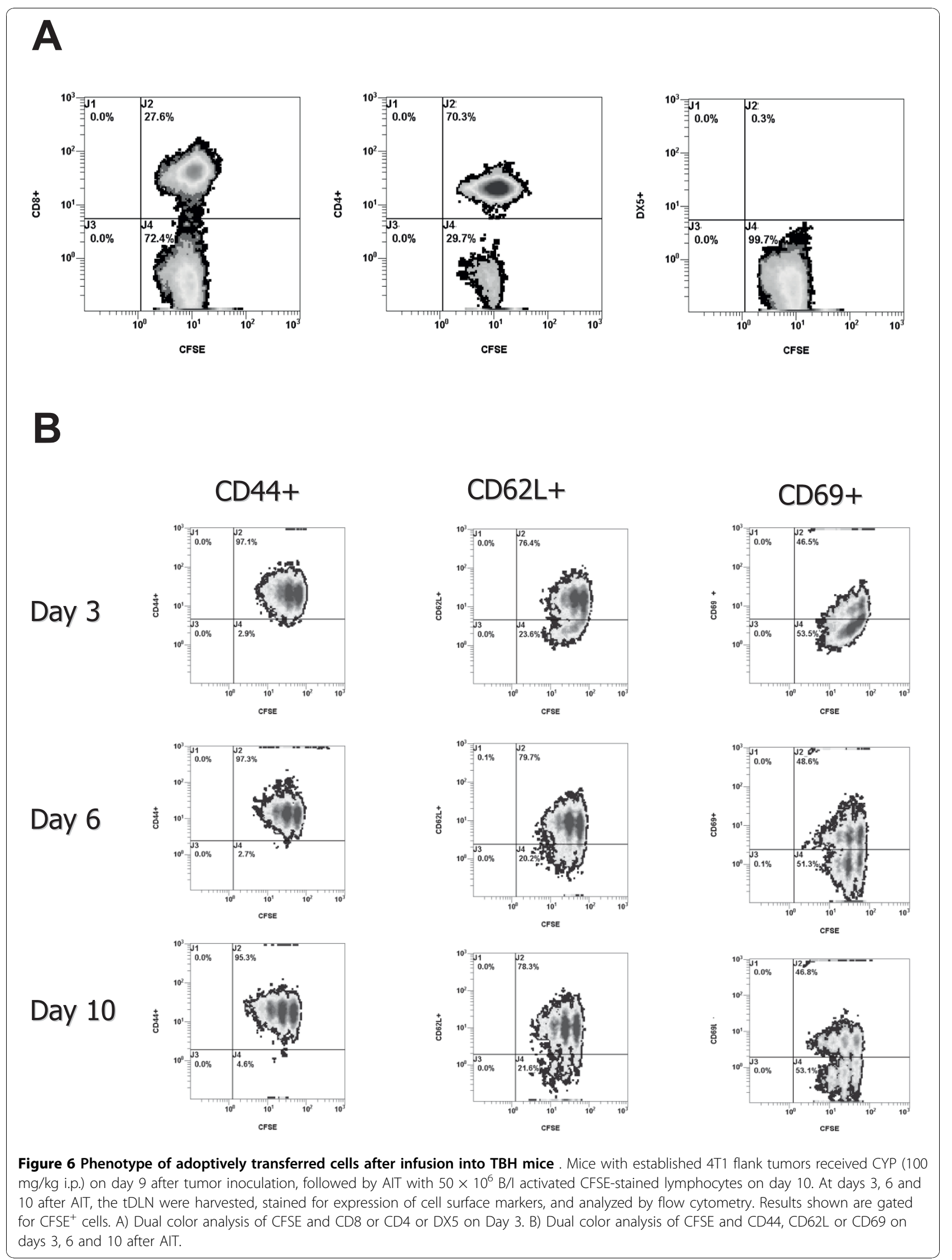




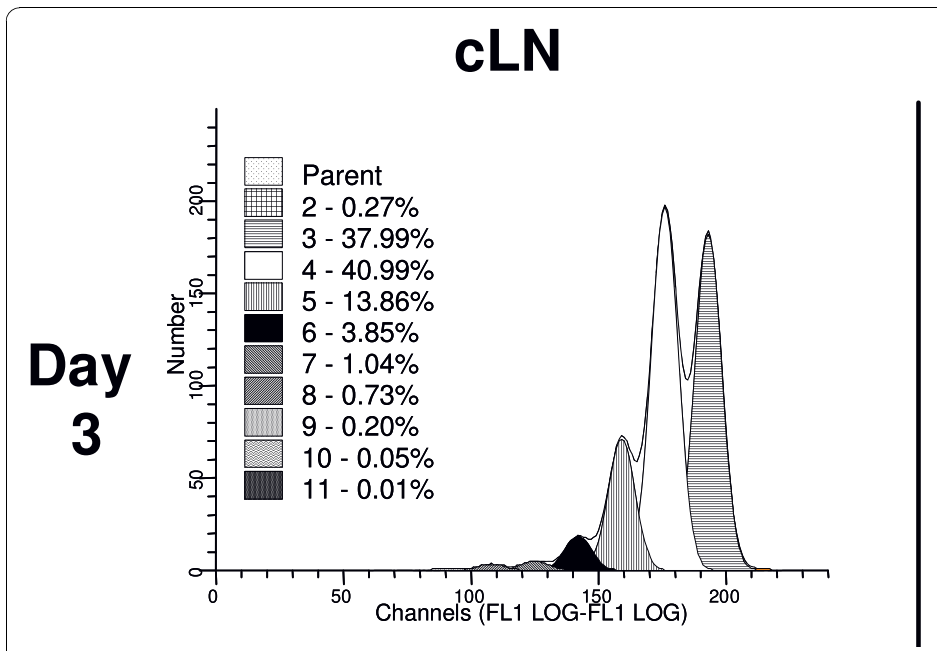

\section{tDLN}

Figure 7 Adoptively transferred B/l-activated cells proliferate in vivo. Mice with established 4T1 flank tumors were treated with CYP on day 9 after tumor inoculation followed by AIT with $50 \times 10^{6}$ CFSE-stained B/I activated lymphocytes from culture (on day 10). At 3 days after AIT, the tDLN, and contralateral LN (CLN) were harvested and analyzed by flow cytometry for CFSE ${ }^{+}$cells. Proliferation and generations of CFSE ${ }^{+}$cells were analyzed with ModFit software. Modfit analysis showed the presence of at least 9 cell generations (Reduced chi-squared $=1.238$ ).

was not as striking on day 6 (67.8 vs. $63.4 \%$, data not shown), but, as shown below, the proliferation is not just dependent on antigen but also may result from the prior stimulation with $\mathrm{B} / \mathrm{I}$ in vitro.

\section{Proliferation in vivo was dependent upon $\mathrm{B} / \mathrm{l}$ activation before adoptive transfer}

To ascertain whether the proliferation we observed in vivo for $\mathrm{B} / \mathrm{I}$ activated $\mathrm{tDLN}$ in $\mathrm{TBH}$ mice resulted simply from homeostatic proliferation after the CYP treatment or is enhanced by the prior B/I stimulation, freshly harvested $\mathrm{tDLN}$ were transferred into CYP pre-treated $\mathrm{TBH}$ mice and $\mathrm{B} / \mathrm{I}$ activated $\mathrm{tDLN}$ were infused into similar hosts, with or without CYP pre-treatment. As shown in Figure 8, adoptively transferred non-activated tDLN did not proliferate significantly, even in mice bearing the relevant tumor and treated with CYP. These cells also did not induce tumor regression (data not shown). In contrast, strong proliferation was seen in $\mathrm{B} / \mathrm{I}$ activated tDLN transferred into TBH, with or without CYP pretreatment (Figure 8). Thus, the proliferation of adoptively transferred cells in $\mathrm{TBH}$ mice was induced neither by CYP pre-treatment of the host before AIT nor by stimulation with tumor antigen, but required $\mathrm{B} / \mathrm{I}$ activation.

\section{How does CYP augment the anti-tumor effect of AIT with B/l-activated lymphocytes?}

We observed slightly greater proliferation of adoptively transferred CFSE-labelled cells in the tDLN of CYP pretreated hosts compared to similar hosts not treated with CYP. In CYP pretreated hosts, $9.38 \%$ of cells were in generation 6 and $5.26 \%$ of cells in generation 7 on day 3 , versus $6.63 \%$ in generation 6 and $2.5 \%$ in generation 7 in mice not treated with CYP. The numbers of adoptively transferred cells in the tDLN of CYP-treated or untreated hosts were roughly similar on days 3 and 7 after adoptive transfer. The number of $\mathrm{CFSE}^{+}$cells declined by day 10 in the tDLN of un-treated hosts $\left(5 \times 10^{4}\right.$ cells vs $3 \times 10^{5}$ cells in CYP pre-treated hosts). CYP pretreatment, therefore, modestly enhanced the proliferation of adoptively transferred cells and the persistence of these cells at later time points in the tDLN.

In order to determine whether CYP pre-treatment altered the functional response or number of responsive $\mathrm{T}$ cells after AIT, the number of cells capable of producing IFN- $\gamma$ in response to $4 \mathrm{~T} 1$ tumor in spleens harvested from untreated $\mathrm{TBH}$ mice, or $\mathrm{TBH}$ mice treated with AIT, with or without CYP pre-treatment, was assessed. As shown in Figure 9A and 9B, the greatest number of cells producing IFN- $\gamma$ in response to $4 \mathrm{~T} 1$ tumor was seen in spleens of mice who received CYP prior to adoptive transfer of $\mathrm{B} / \mathrm{I}$ activated cells.

\section{Discussion}

In this and previous studies, we have demonstrated that B/I activation of tDLN cells produces a population of cells with potent anti-tumor activity against established tumors up to 10 days after inoculation. Even tDLN harvested from donors 20 days post-tumor inoculation, from a metastatic disease state and possibly immunosuppressive milieu, are capable of inducing tumor regression after B/I activation and adoptive transfer into tumor bearing hosts. 14 days after tumor inoculation, $80 \%$ of 4T1-tumor bearing mice have measurable metastatic disease, and by 18 days, $100 \%$ have lung metastases [31]. We had previously shown that B/I preferentially activated 


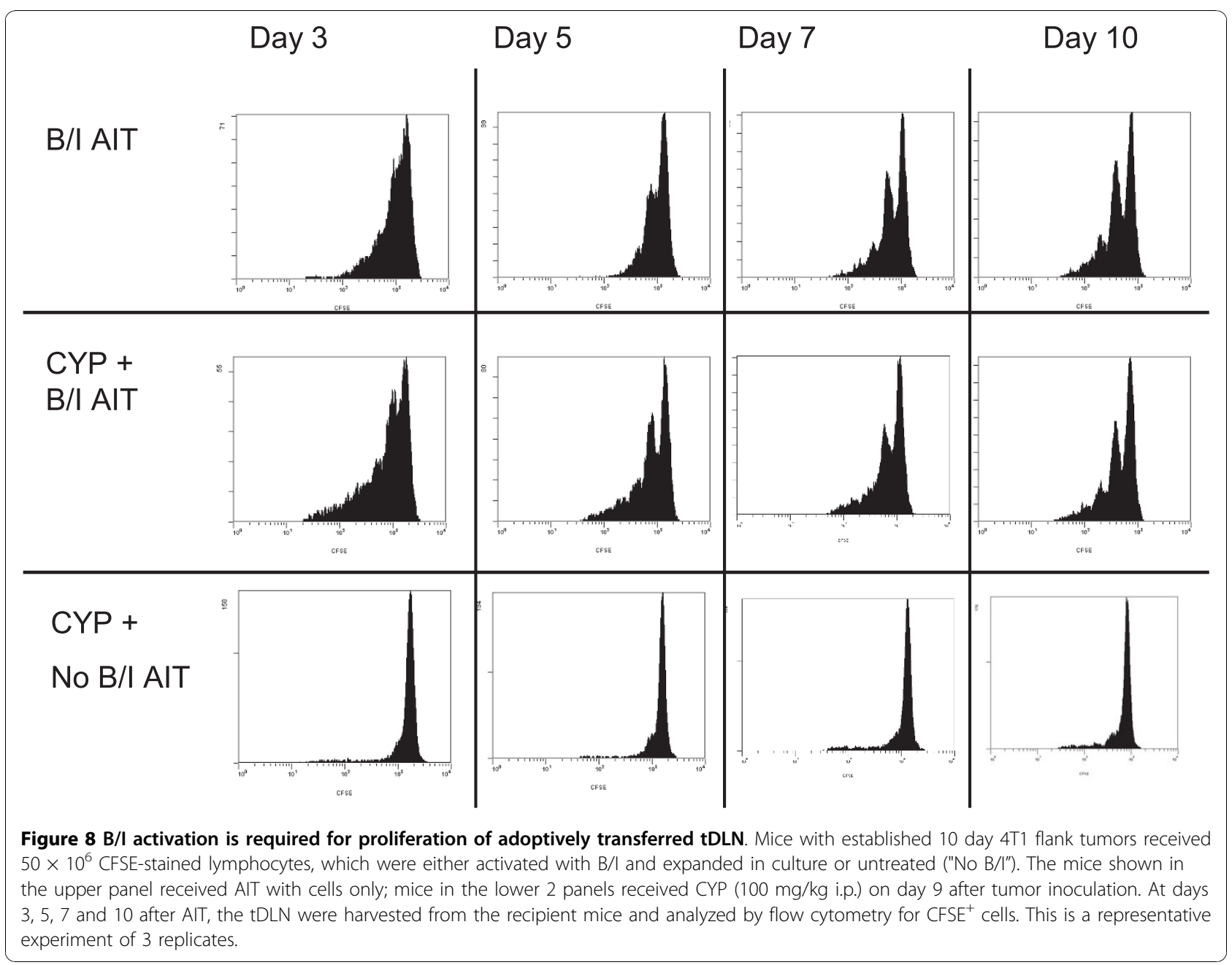

a subset of tDLN cells that were initially CD62 $\mathrm{L}^{-}$and that these cells accounted for all of the subsequently developed anti-tumor activity [28]. In the present studies, we have further characterized the post-activation phenotype and the in vivo trafficking, and proliferation of the antitumor effector cells generated by B/I activation and expansion in culture. The most potent anti-tumor effector cells were highly activated $\mathrm{CD} 8^{+} \mathrm{T}$ cells which remained $\mathrm{CD}^{2} 2 \mathrm{~L}^{-}$after $\mathrm{B} / \mathrm{I}$ activation and expansion. These cells also respond to tumor antigen by specific release of IFN- $\gamma$, which we and others have shown correlates with anti-tumor activity [31-37].

Recently, there have been a number of reports that either central memory and/or early effector $\mathrm{T}$ cells are the most effective cell types for AIT [38,39]. Conversion of adoptively transferred cells to the central memory phenotype has also been observed in adoptive hosts [40]. $T_{C M}$ cells or early effector cells, as opposed to fully differentiated effector or effector memory $\left(\mathrm{T}_{\mathrm{EM}}\right)$ cells, have been found to have a greater ability to home to lymphoid tissue via expression of CD62L and CCR7, produce IL-2, proliferate more rapidly in response to antigen and cytokines, and then differentiate into effector cells [41-43]. $\mathrm{T}_{\mathrm{EM}}$ cells lack lymph node homing receptors, exhibit direct (ex vivo) cytotoxic activity, do not produce IL-2, and are found in non-lymphoid tissues [44-46]. Thus, $\mathrm{T}_{\mathrm{CM}}$ cells, despite a lower level of immediate effector functions, may be more effective for AIT, because they produce a larger number of antitumor cells for a longer period of time. As $\mathrm{T}$ cells are repeatedly stimulated, they differentiate from early effector to effector to late effector memory cells. They also downregulate receptors for homeostatic cytokines, and upregulate pro-apoptotic molecules.

We found that after 18 hour $\mathrm{B} / \mathrm{I}$ activation and 7 days of expansion in IL-2, the initially CD62 $\mathrm{L}^{-}$effector cell population harvested from donor mice had largely upregulated the expression of CD62L (up to $68 \% \mathrm{CD}^{2} \mathrm{~L}^{+}$). We also observed up-regulation of memory markers CD27, CD44, CD69, and CD127. Furthermore, 76.4\% of the adoptively transferred cells that were isolated from the adoptive hosts' tDLN 3 days after AIT were CD62L ${ }^{+}$, 

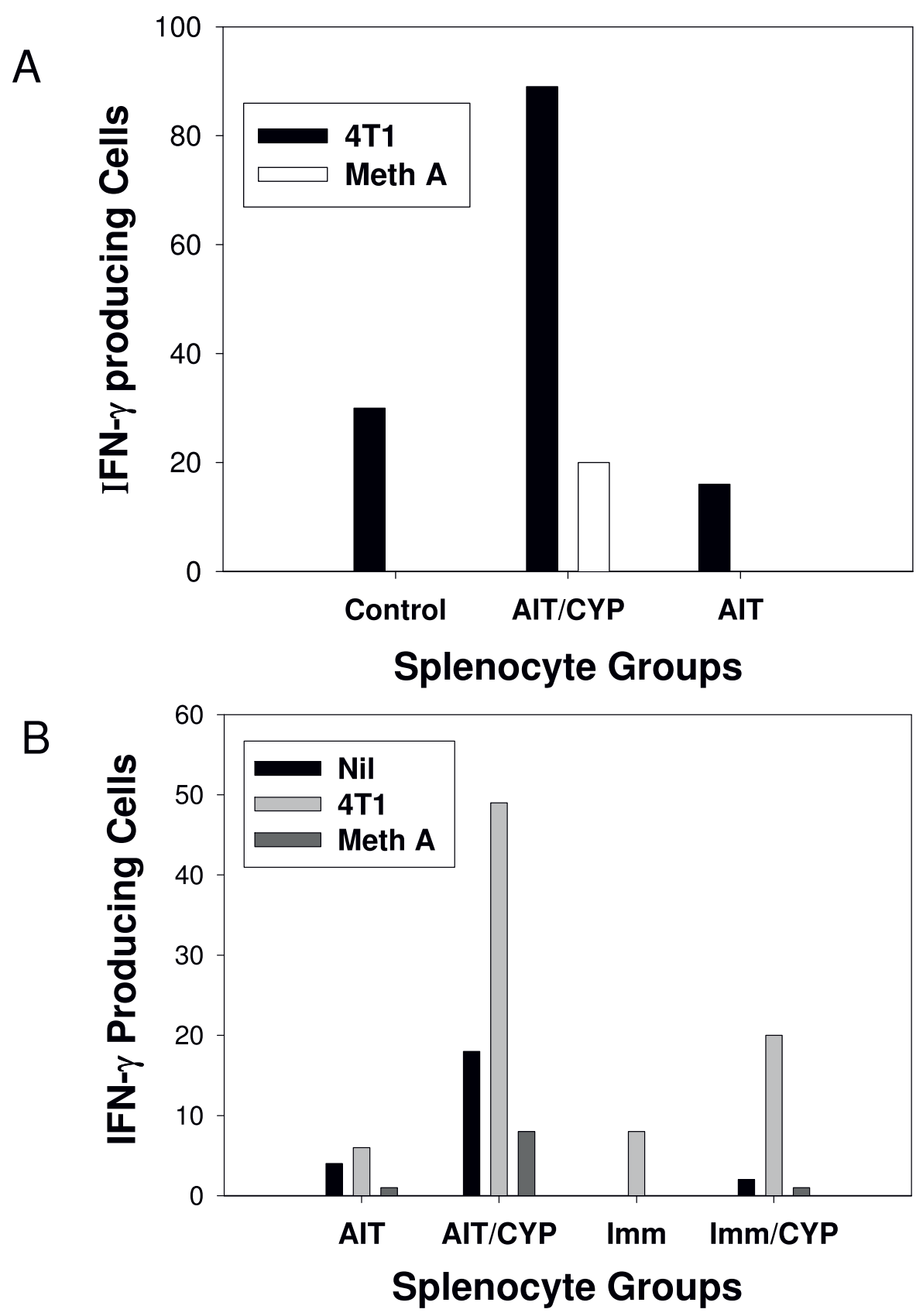

Figure 9 CYP treatment of AIT recipients increases the number of lymphocytes which produce IFN- $\gamma$ in response to 4 T1 tumor cells. A) ELIspot assays for IFN- $\gamma$ producing cells from spleens of mice with established 10 day 4T1 flank tumors which were either untreated, or received AIT with $50 \times 10^{6} \mathrm{~B} / \mathrm{l}$ activated lymphocytes, with or without CYP pre-treatment (100 mg/kg IP) on day 9 . Splenocytes harvested from recipient mice 5 days after AIT were stimulated with 4T1 or MethA sarcoma cells and the number of cells producing IFN- $\gamma$ were enumerated. Results are pooled from 3 mice in each group, mean values from paired wells are shown, and are representative of 3 replicate experiments B) ELIspot assays for IFN- $\gamma$ producing cells from spleens of mice with established 10 day $4 \mathrm{~T} 1$ flank tumors which were either untreated, received AIT with $50 \times 10^{6}$ B/I activated lymphocytes, with or without CYP pre-treatment (100 mg/kg IP) on day 9, immunized with irradiated 4T1 cells with or without CYP pre-treatment $(100 \mathrm{mg} / \mathrm{kg} \mathrm{IP})$ on day 9 . Splenocytes harvested from recipient mice 8 days after AIT were stimulated with 4T1 or MethA sarcoma cells and the number of cells producing IFN- $\gamma$ were enumerated. Results are pooled from 3 mice in each group, mean values from paired wells are shown, and are representative of 3 replicate experiments. 
which suggested that activation with $\mathrm{B} / \mathrm{I}$ may stimulate sensitized or CD62 $\mathrm{L}^{-} \mathrm{T}_{\mathrm{EM}}$ (CD62 $\mathrm{L}^{-} \mathrm{CCR} 7^{\text {low }}, \mathrm{CD} 27^{+}$, BCL-2 ${ }^{\text {hi }}$ ) or effector $\mathrm{T}$ cells to shift to a CD62 $\mathrm{L}^{+} \mathrm{T}_{\mathrm{CM}}$ phenotype, which we initially supposed would be largely responsible for the anti-tumor effects we have observed.

However, we found instead that adoptive transfer of $\mathrm{B} / \mathrm{I}$ activated and expanded CD62 $\mathrm{L}^{-}$cells (separated after expansion in culture) were most effective at mediating tumor regression, and that the $\mathrm{CD} 2 \mathrm{~L}^{+}$fraction had little or no anti-tumor activity. There are a few explanations for these somewhat unexpected results and how it differs from previous reports. For example, this result may reflect enrichment of tumor antigen specific Treg cells in the CD62 $\mathrm{L}^{+}$subset, as recently reported [47]. Alternatively, the $\mathrm{CD}^{2} 2 \mathrm{~L}^{-}$cells present after $\mathrm{B} / \mathrm{I}$ activation and expansion may be analogous to secondary response derived memory cells, which are $\mathrm{CD}^{2} \mathrm{~L}^{-}$[48]. Recent literature suggests a distinct phenotype for $\mathrm{T}$ memory cells derived from primary versus those from secondary immune responses [45] [48-52]. CD8 T cells undergoing a secondary response expand more rapidly and divide at a faster rate than in a primary response [53]. In the Listeria monocytogenes (LM), Lymphocytic Choriomeningitis Virus (LCMV), and TcR transgenic models, it has been found that secondary immune responses produced memory CD $8 \mathrm{~T}$ cells which are slow to convert to $\mathrm{T}_{\mathrm{CM}}$, as measured by both CD62L expression and antigen induced IL-2 production [51]. Primary and secondary response memory CD8 T cells have equal proliferative capacities in respect to numbers of generations, but secondary memory CD8 T cells remain $\mathrm{CD}_{62} \mathrm{~L}^{\text {low }}$, in contrast to the $\mathrm{CD} 62 \mathrm{~L}^{\text {high }}$ memory CD8 cells resulting from primary responses. Moreover, secondary CD62 $\mathrm{L}^{\text {low }}$ memory cells are more effective against virulent LM infection and have increased cytolytic activity [48]. The CD62 $\mathrm{L}^{-} \mathrm{T}$ cells harvested from culture after $\mathrm{B} / \mathrm{I}$ activation and expansion may be more analogous to memory cells derived from a secondary response, which our protocol mimics by re-activation of antigen-sensitized $\mathrm{T}$ cells with $\mathrm{B} / \mathrm{I}$. This contrasts with the $\mathrm{T}_{\mathrm{EM}}$ or $\mathrm{T}_{\mathrm{CM}}$ cells generated by stimulating naive pmel-1 TcR transgenic $\mathrm{T}$ cells with antigen and cytokines in vitro [38,39]. These approaches would generate $\mathrm{T}_{\mathrm{CM}} \mathrm{CD} 8$ cells of the primary type, with the secondary immune response not occurring until after adoptive transfer into the tumor bearing host and subsequent in vivo vaccination with fowlpox vaccine encoding hgp100 [38,39]. In our model, the primary immune response occurs in vivo in the tDLNs of the donor mice, and the secondary immune response occurs in vitro upon $\mathrm{B} / \mathrm{I}$ activation of the tDLN. Our model may be more analagous with the clinical situation, in which sensitized PBMCs, tDLN, or vDLN are isolated from cancer patients, activated and expanded in vitro, and secondary memory $\mathrm{T}$ cells are then adoptively transferred into patients. Thus, B/I may have the advantage of generating secondary type $\mathrm{T}$ memory cells for adoptive transfer.

To further characterize the nature of the anti-tumor effector cells and their CD62L phenotype, tDLN lymphocytes were separated by CD62L phenotype both before and after $\mathrm{B} / \mathrm{I}$ expansion. The most potent antitumor cells were the $\left(\mathrm{CD} 62 \mathrm{~L}^{-} \rightarrow \mathrm{CD} 62 \mathrm{~L}^{-}\right)$cells, which were capable of inducing tumor regression when as few as $375,000 \mathrm{~B} / \mathrm{I}$ activated cells were transferred and even when double the normal tumor cell inoculum was used to establish the tumors. Studies with CFSE labeled cells showed that the adoptively transferred $\left(\mathrm{CD} 62 \mathrm{~L}^{-}\right.$ $\rightarrow \mathrm{CD} 2 \mathrm{~L}^{-}$) subset, despite the lack of CD62L, were able to traffic to tDLN after adoptive transfer, proliferated extensively in the adoptive hosts, and maintained their lack of CD62L expression (data not shown). $\mathrm{H}$ The $\left(\mathrm{CD} 2 \mathrm{~L}^{-} \rightarrow \mathrm{CD}^{-} \mathrm{L}^{+}\right.$) subset was less effective than $\left(\mathrm{CD} 2 \mathrm{~L}^{-} \rightarrow \mathrm{CD} 2 \mathrm{~L}^{-}\right)$cells at inducing tumor regression, especially at higher tumor inocula. Surprisingly, (CD62L $\left.{ }^{+} \rightarrow \mathrm{CD} 6 \mathrm{~L}^{-}\right)$cells were capable of delaying tumor progression. We previously had not seen any evidence of anti-tumor activity from initially $\mathrm{CD} 6 \mathrm{~L}^{+}$subsets. These $\left(\mathrm{CD} 62 \mathrm{~L}^{+} \rightarrow \mathrm{CD} 6 \mathrm{~L}^{-}\right)$cells may be tumor specific early effector or memory cells when harvested from donor mice and then may acquire an effector phenotype after exposure to $\mathrm{B} / \mathrm{I}$. The existence of these cells may have been masked in previous experiments in which separations were done either before or after B/I activation. When the CD62L separation was carried out only before $\mathrm{B} / \mathrm{I}$ activation and expansion, they would have been vastly outnumbered by the ineffective $\left(\mathrm{CD} 62 \mathrm{~L}^{+}\right.$ $\rightarrow \mathrm{CD} 2 \mathrm{~L}^{+}$) subset and possibly suppressed by any Treg $\left(\mathrm{CD} 4^{+} \mathrm{CD} 25^{+}\right)$cells also present in that fraction. When CD62L separation was carried out only after B/I activation and expansion, these cells would have been in the CD62 $\mathrm{L}^{-}$subset. We have repeated these experiments with similar results, in both the B16 melanoma and B16-OVA models, indicating that this is not a tumor model specific result (data not shown).

Adoptively transferred cells were shown to persist and/or proliferate preferentially in hosts bearing the relevant tumor and accumulated preferentially in tumor draining lymph nodes. The decline in adoptively transferred cells in the spleens after day 3 is consistent with trafficking of these cells to sites of tumor antigen concentration. The low number of $\mathrm{CFSE}^{+}$cells seen in the tumors may reflect proliferation of the cells beyond the limits of dye detection; after generation 10-12, CFSE becomes too dilute to be readily detected. Using immunohistochemical staining of tumors (not shown), both $\mathrm{CD}_{4}^{+}$and $\mathrm{CD}^{+}$cells were observed to infiltrate into tumors, although $\mathrm{CD}^{+}$cells do not appear to be required for tumor regression. Although some of these 
infiltrating cells could be of host origin, we have found that AIT is effective in nude mice [not shown and [31]], suggesting that host $\mathrm{T}$ cells are also not required.

In our model, the increased numbers of adoptively transferred cells in the tDLN suggest that specific uptake and/or proliferation of lymphocytes occurred at the site of antigen and antigen-presenting cells. However, it is not possible to tell how much of the difference in the numbers of cells at the tDLN vs the cLN is due to specific trafficking and accumulation at the site of the tDLN and how much is due to increased proliferation in the tDLN. In fact, we did also observe increased proliferation of the adoptively transferred cells in the tDLN as compared to the cLN, especially on day 3 . However, in the absence of specific tumor antigen, adoptively transferred cells did not persist in the host LN. Thus, accumulation of adoptively transferred lymphocytes in the tDLN seems to be specific for tumor antigen, and not merely a result of non-specific inflammation.

In contrast to our trafficking results, others have reported that trafficking and accumulation of infused $\mathrm{T}$ cells in TBH mice was indiscriminate, without preference for tumor-draining $\mathrm{LN}$ versus other $\mathrm{LN}[38,39]$. It is important to note, however, that after infusion of $\mathrm{T}$ cells in those experiments, the adoptive hosts received systemic antigen, in the form of a recombinant fowlpox vaccine, as well as exogenous cytokines. Both of these would be expected to result in stimulation and proliferation of the adoptively transferred cells throughout the adoptive host $[38,39]$. Furthermore, the TcR transgenic T cells that were infused in that model recognize a self antigen that would be expected to be present throughout the host, not only at the site of tumor growth or the tDLN.

In our model, proliferation of the adoptively transferred cells in the host was also dependent upon prior $\mathrm{B} / \mathrm{I}$ activation; we did not observe proliferation of unactivated tDLN lymphocytes after adoptive transfer, even in CYP-pretreated hosts. Thus, the proliferation seen in our protocol is a result of $\mathrm{B} / \mathrm{I}$ activation, and not merely homeostatic proliferation. One of the key potential advantages of $\mathrm{B} / \mathrm{I}$ activation of tDLN is the ability of these cells to continue proliferating in adoptive hosts after AIT, without the need for exogenous cytokines or antigen vaccination. Interestingly, at the time these cells are harvested from culture, proliferation in vitro is generally declining, but apparently accelerates again in vivo.

In previous studies, we have shown that adoptively transferred B/I activated lymphocytes were more effective at inducing tumor regression in combination with CYP pre-treatment. The effectiveness of $\mathrm{B} / \mathrm{I}$ activated lymphocytes with CYP pre-treatment and the lack of requirement for exogenous cytokine therapy is a major advantage of our method of activating tDLN. Several different mechanisms may account for CYP mediated modulation of the immune system. Several studies suggest that CYP causes a breakdown of regulatory mechanisms by removal of a suppressor cell population [54-58]. In early studies, mice that were pre-treated with CYP 2-3 days in advance of sensitization exhibited enhanced contact sensitivity or delayed type hypersensitivity [58-60]. Recent data suggest that CYP may selectively inhibit or deplete CD4+ CD25+ Treg cells [61-65]. CYP may also enhance AIT by temporarily inhibiting tumor growth, by creating "space" for $\mathrm{T}$ cell growth, or by a relative increase in cytokines that stimulate $\mathrm{T}$ cell proliferation [66].

As noted earlier, in the absence of B/I activation, adoptively transferred cells did not proliferate in CYP pretreated hosts, indicating that CYP alone does not lead to homeostatic proliferation of adoptively transferred cells and that $\mathrm{B} / \mathrm{I}$ activation was required for the proliferation of these cells in vivo. B/I activated lymphocytes, on the other hand, proliferated in the adoptive hosts with or without CYP pre-treatment. Arguably, slightly more proliferation was seen in CYP pre-treated hosts, but what was more striking was the increase in tumor antigen specific IFN- $\gamma$-producing cells in CYP pre-treated hosts compared to untreated hosts. Pre-treatment with CYP before AIT, it would appear, increases the resulting number of IFN- $\gamma$ producing cells, possibly from the increase in availability of homeostatic cytokines or the removal of suppressive Treg populations.

\section{Conclusions}

$\mathrm{B} / \mathrm{I}$ activation of tDLN generates large numbers of potent anti-tumor effector tells, as demonstrated by tumor regression in vivo and production of IFN- $\gamma$ in vitro. These cells have the ability to traffic to the tumor draining lymph nodes, to proliferate extensively in vivo and to mediate tumor regression. Pre-treatment with CYP enhances the efficacy of adoptive immunotherapy, by increasing the number of resulting IFN- $\gamma$ producing cells. The predominant mediators of anti-tumor activity are $\mathrm{CD}^{+}{ }^{+} \mathrm{T}$ cells which are intially $\mathrm{CD} 62 \mathrm{~L}^{-}$when harvested from tDLN donors and remain $\mathrm{CD}^{2} 2 \mathrm{~L}^{-}$after $\mathrm{B} / \mathrm{I}$ activation and expansion.

The results reported here will be used to distinguish more precisely the most effective anti-tumor populations in the tDLN and to explore methods of generating more of these cells. B/I activation is unique in that it is capable of selectively activating only sensitized $\mathrm{T}$ cells, appears to generate highly effective $\mathrm{T}$ cells of a secondary memory phenotype, and perhaps for that reason, does not require exogenous cytokines to be administered to the adoptive tumor-bearing host. This could avoid much of the toxicity associated with some AIT regimens. We are currently exploring the use of alternate $\gamma$-chain cytokines instead of IL-2 to program even 
more effectively the phenotypic development of B/I activated $\mathrm{tDLN}$ to a $\mathrm{T}$ memory phenotype, while decreasing the potential for expanding Treg cells.

\section{Abbreviations}

Abs: antibodies; AIT: adoptive immunotherapy; ANOVA: analysis of variance; B/I: bryostatin and ionomycin; C': complement; CFDA-SE: Carboxyfluorescein Diacetate Succinimidyl Ester; CFSE: carboxyfluoroscein succinimidyl ester; CLN: contralateral lymph node; CTL: cytotoxic T lymphocytes; CYP: cyclophosphamide; DLN: draining lymph node; IFN- $\gamma$ : Interferon- $\gamma$; IP: intraperitoneal; IV: intravenously; LCMV: Lymphocytic Choriomeningitis Virus; LM: Listeria monocytogenes; mAb: monoclonal antibody; PBMC: peripheral blood mononuclear cells; TBH: tumor bearing host; $T_{C M}$ : central memory $T$ cells; TCR: T cell receptor; tDLN: tumor draining lymph node; $T_{E M}$ : effector memory T cells; Treg: T regulatory cells; Tukey's HSD: Tukey-Kramer honestly significant difference test.
\end{abstract}

\section{Acknowledgements}

Flow Cytometry supported in part by NIH Grant P30 CA16059. Research was supported by R01 CA48075 and T32 A1074707-12 grants from the NIH, and DHHS. Additional support provided by A.D. Williams Grant \# 6-40438.

\section{Author details}

'Department of Microbiology and Immunology, Virginia Commonwealth University's Medical College of Virginia, Richmond, Virginia, USA. ${ }^{2}$ Division of Surgical Oncology, Department of Surgery, Virginia Commonwealth University's Medical College of Virginia and the Massey Cancer Center, Richmond Virginia, USA.

\section{Authors' contributions}

CM carried out the immunotherapy protocols, immunostaining and flow cytometric analysis, carried out the statistical analysis and drafted the manuscript. LG performed the ELIspot assays and participated in the design of the studies. HB conceived of the study, participated in it's design and coordination and helped to draft the manuscript. All authors read and approved of the final manuscript.

Received: 11 January 2010 Accepted: 4 November 2010 Published: 4 November 2010

\section{References}

1. Saleh F, Renno W, Klepacek I, Ibrahim G, Dashti H, Asfar S, Behbehani A, AlSayer H, Dashti A: Direct evidence on the immune-mediated spontaneous regression of human cancer: an incentive for pharmaceutical companies to develop a novel anti-cancer vaccine. Curr Pharm Des 2005, 11:3531-3543.

2. Saleh FH, Crotty KA, Hersey P, Menzies SW: Primary melanoma tumour regression associated with an immune response to the tumourassociated antigen melan-A/MART-1. Int I Cancer 2001, 94:551-557.

3. Boon T, Cerottini IC, Van den Eynde B, Van der Bruggen P, Van Pel A: Tumor antigens recognized by T lymphocytes. Annu Rev Immunol 1994, 12:337-365.

4. Chang AE, Li Q, Jiang G, Sayre DM, Braun TM, Redman BG: Phase II trial of autologous tumor vaccination, anti-CD3-activated vaccine-primed lymphocytes, and interleukin-2 in stage IV renal cell cancer. J Clin Oncol 2003, 21:884-890.

5. Cohen PA, Peng LM, Kjaergaard J, Plautz GE, Finke JH, Koski GK, Czerniecki BJ, Shu SY: T-cell adoptive therapy of tumors: Mechanisms of improved therapeutic performance. Crit Rev Immunol 2001, 21:215-248.

6. Crossland KD, Lee VK, Chen W, Riddell SR, Greenberg PD, Cheever MA: T cells from tumor-immune mice nonspecifically expanded in vitro with anti-CD3 plus IL-2 retain specific function in vitro and can eradicate disseminated leukemia in vivo. J Immunol 1991, 146:4414-4420.

7. Dudley ME, Rosenberg SA: Adoptive-cell-transfer therapy for the treatment of patients with cancer. Nat Rev Cancer 2003, 3:666-675.

8. Goedegebuure PS, Douville LM, Li H, Richmond GC, Schoof DD, Scavone M, Eberlein TJ: Adoptive immunotherapy with tumor-infiltrating lymphocytes and interleukin-2 in patients with metastatic malignant melanoma and renal cell carcinoma: A pilot study. J Clin Oncol 1995, 13:1939-1949.

9. Harada M, Okamoto T, Omoto K, Tamada K, Takenoyama M, Hirashima C, Ito O, Kimura G, Nomoto K: Specific immunotherapy with tumourdraining lymph node cells cultured with both anti-CD3 and anti-CD28 monoclonal antibodies. Immunol 1996, 87:447-453.

10. Morse MA, Clay TM, Lyerly HK: Current status of adoptive immunotherapy of malignancies. Expert Opin Biol Ther 2002, 2:237-247.

11. Nijhuis EWP, Wiel-van Kemenade EVD, Figdor CG, Van Lier RAW: Activation and expansion of tumour-infiltrating lymphocytes by anti-CD3 and antiCD28 monoclonal antibodies. Cancer Immunol Immunother 1990, 32:245-250.

12. Plautz GE, Cohen PA, Shu S: Considerations on clinical use of $\mathrm{T}$ cell immunotherapy for cancer. Arch. Immunol Ther Exp (Warsz) 2003, 51:245-257.

13. Ribas A, Butterfield LH, Glaspy JA, Economou JS: Current developments in cancer vaccines and cellular immunotherapy. J Clin Oncol 2003, 21:2415-2432.

14. Schoof DD, Selleck CM, Massaro AF, Jung SE, Eberlein TJ: Activation of human tumor-infiltrating lymphocytes by monoclonal antibodies directed to the CD3 complex. Cancer Res 1990, 50:1138-1143.

15. Yoshizawa $H$, Chang AE, Shu S: Specific adoptive immunotherapy mediated by tumor-draining lymph node cells sequentially activated with anti-CD3 and IL-2. J Immunol 1991, 147:729-737.

16. Alexander JP, Kudoh S, Melsop KA, Hamilton TA, Edinger MG, Tubbs RR, Sica D, Tuason L, Klein E, Bukowski RM: T-cells infiltrating renal cell carcinoma display a poor proliferative response even though they can produce interleukin 2 and express interleukin 2 receptors. Cancer Res 1993, 53:1380-1387.

17. Correa MR, Ochoa AC, Ghosh P, Mizoguchi H, Harvey L, Longo DL: Sequential development of structural and functional alterations in $T$ cells from tumor-bearing mice. J Immunol 1997, 158:5292-5296.

18. Danna EA, Sinha P, Gilbert M, Clements VK, Pulaski BA, OstrandRosenberg S: Surgical removal of primary tumor reverses tumor-induced immunosuppression despite the presence of metastatic disease. Cancer Res 2004, 64:2205-2211.

19. Tuttle TM, Inge TH, Bethke KP, McCrady CW, Pettit GR, Bear HD: Activation and growth of murine tumor-specific T-cells which have in vivo activity with bryostatin 1. Cancer Res 1992, 52:548-553.

20. Tuttle TM, Bethke KP, Inge TH, McCrady CW, Pettit GR, Bear HD: Bryostatin 1-activated T cells can traffic and mediate tumor regression. J Surg Res 1992, 52:543-548.

21. Tuttle TM, McCrady CW, Inge TH, Salour M, Bear HD: $\gamma$-interferon plays a key role in T-cell-induced tumor regression. Cancer Res 1993, 53:833-839.

22. Tuttle TM, Fleming MF, Hogg PS, Inge TH, Bear HD: Low-dose cyclophosphamide overcomes metastasis-induced immunosuppression. Ann Surg Oncol 1994, 1:53-58.

23. Yee C: Adoptive T cell therapy-immune monitoring and MHC multimers. Clin Immunol 2003, 106:5-9.

24. Cantrell D: T cell antigen receptor signal transduction pathways. Annu Rev Immunol 1996, 14:259-274.

25. Kazanietz MG, Lewin NE, Gao F, Pettit GR, Blumberg PM: Binding of $\left[26-{ }^{3} \mathrm{H}\right]$ bryostatin 1 and analogs to calcium- dependent and calciumindependent protein kinase C isozymes. Mol Pharmacol 1994, 46:374-379.

26. Pettit GR, Herald SL, Doubek DL, Arnold E, Clardy J: Isolation and structure of bryostatin 1. J Am Chem Soc 1982, 104:6846-6848.

27. Chatila T, Silverman L, Miller R, Geha R: Mechanisms of $T$ cell activation by the calcium ionophore ionomycin. J Immunol 1989, 143:1283-1289.

28. Chin CS, Miller CH, Graham L, Parviz M, Zacur S, Patel B, Duong A, Bear HD: Bryostatin 1/ionomycin (B/I) ex vivo stimulation preferentially activates L-selectin ${ }^{\text {low }}$ tumor-sensitized lymphocytes. Int Immunol 2004, 16:1283-1294.

29. Kagamu H, Shu SY: Purification of L-selectin ${ }^{\text {low }}$ cells promotes the generation of highly potent CD4 antitumor effector T lymphocytes. J Immunol 1998, 160:3444-3452.

30. Kjaergaard J, Shu SY: Tumor infiltration by adoptively transferred T cells is independent of immunologic specificity but requires down-regulation of L-selectin expression. J Immunol 1999, 163:751-759.

31. Parviz M, Chin CS, Graham LJ, Miller C, Lee C, George K, Bear HD: Successful adoptive immunotherapy with vaccine-sensitized T cells, 
despite no effect with vaccination alone in a weakly immunogenic tumor model. Cancer Immunol Immunother 2003, 52:739-750.

32. Aruga A, Aruga E, Tanigawa K, Bishop DK, Sondak VK, Chang AE: Type 1 versus type 2 cytokine release by $\mathrm{Vb} \mathrm{T}$ cell subpopulations determines the in vivo antitumor reactivity: IL-10 mediates a suppressive role. J Immunol 1997, 159:664-673.

33. Lowes MA, Bishop GA, Crotty K, Barnetson RS, Halliday GM: T helper 1 cytokine mRNA is increased in spontaneously regressing primary melanomas. J Invest Dermatol 1997, 108:914-919.

34. Tsung $K$, Meko JB, Peplinski GR, Tsung TL, Norton JA: IL-12 induces T helper-1 directed antitumor responses. J Immunol 1997, 158:3359-3365.

35. Winter H, Hu HM, McClain K, Urba WJ, Fox BA: Immunotherapy of melanoma: A dichotomy in the requirement for IFN- $\gamma$ in vaccineinduced antitumor immunity versus adoptive immunotherapy. $J$ Immunol 2001, 166:7370-7380.

36. Zitvogel L, Mayordomo Jl, Tjandrawan T, Deleo AB, Clarke MR, Lotze MT, Storkus WJ: Therapy of murine tumors with tumor peptide-pulsed dendritic cells: Dependence on T cells, B7 costimulation, and T helper cell 1-associated cytokines. J Exp Med 1996, 183:87-97.

37. Hu HM, Urba WJ, Fox BA: Gene-modified tumor vaccine with therapeutic potential shifts tumor-specific $T$ cell response from type 2 to type 1 cytokine profile. J Immunol 1998, 161:3033-3041.

38. Gattinoni L, Klebanoff CA, Palmer DC, Wrzesinski C, Kerstann K, Yu Z, Finkelstein SE, Theoret MR, Rosenberg SA, Restifo NP: Acquisition of full effector function in vitro paradoxically impairs the in vivo antitumor efficacy of adoptively transferred CD8(+) T cells. J Clin Invest 2005, 115:1616-1626.

39. Klebanoff CA, Gattinoni L, Torabi-Parizi P, Kerstann K, Cardones AR, Finkelstein SE, Palmer DC, Antony PA, Hwang ST, Rosenberg SA, Waldmann TA, Restifo NP: Central memory self/tumor-reactive CD8+ T cells confer superior antitumor immunity compared with effector memory T cells. Proc Natl Acad Sci USA 2005, 102:9571-9576.

40. Wrzesinski C, Restifo NP: Less is more: lymphodepletion followed by hematopoietic stem cell transplant augments adoptive T-cell-based antitumor immunotherapy. Curr Opin Immunol 2005, 17:195-201.

41. Wherry EJ, Ahmed R: Memory CD8 T-cell differentiation during viral infection. J Virol 2004, 78:5535-5545.

42. Wherry EJ, Teichgraber V, Becker TC, Masopust D, Kaech SM, Antia R, Von Andrian $\mathrm{UH}$, Ahmed R: Lineage relationship and protective immunity of memory CD8 T cell subsets. Nat Immunol 2003, 4:225-234.

43. Sallusto F, Geginat J, Lanzavecchia A: Central memory and effector memory T cell subsets: function, generation, and maintenance. Annu Rev Immunol 2004, 22:745-63.

44. Lanzavecchia A, Sallusto F: Understanding the generation and function of memory T cell subsets. Curr Opin Immunol 2005, 17:326-332.

45. Roberts AD, Ely KH, Woodland DL: Differential contributions of central and effector memory T cells to recall responses. J Exp Med 2005, 202:123-133.

46. Tough DF: Deciphering the relationship between central and effector memory CD8+ T cells. Trends Immunol 2003, 24:404-407.

47. Hiura T, Kagamu H, Miura S, Ishida A, Tanaka H, Tanaka J, Gejyo F, Yoshizawa $\mathrm{H}$ : Both regulatory $\mathrm{T}$ cells and antitumor effector $\mathrm{T}$ cells are primed in the same draining lymph nodes during tumor progression. $J$ Immunol 2005, 175:5058-5066.

48. Jabbari A, Harty JT: The generation and modulation of antigen-specific memory CD8 T cell responses. J Leukoc Biol 2006, 80:16-23.

49. Badovinac VP, Porter BB, Harty JT: Programmed contraction of CD8(+) T cells after infection. Nat Immunol 2002, 3:619-626.

50. Barber DL, Wherry EJ, Ahmed R: Cutting edge: rapid in vivo killing by memory CD8 T cells. J Immunol 2003, 171:27-31.

51. Jabbari A, Harty JT: Secondary memory CD8+ T cells are more protective but slower to acquire a central-memory phenotype. J Exp Med 2006, 203:919-932.

52. Roberts AD, Woodland DL: Cutting edge: effector memory CD8+ T cells play a prominent role in recall responses to secondary viral infection in the lung. J Immunol 2004, 172:6533-6537.

53. Veiga-Fernandes H, Walter U, Bourgeois C, McLean A, Rocha B: Response of naive and memory $\mathrm{CD} 8^{+} \mathrm{T}$ cells in antigen stimulation in vivo. Nature Immunology 2000, 1:47-53.
54. Polak L, Geleick H, Turk JL: Reversal by cyclophosphamide of tolerance in contact sensitization. Tolerance induced by prior feeding with DNCB. Immunology 1975, 28:939-942.

55. Yasunami R, Bach JF: Anti-suppressor effect of cyclophosphamide on the development of spontaneous diabetes in NOD mice. Eur J Immunol 1988, 18:481-484,

56. Mitsuoka A, Baba M, Morikawa S: Enhancement of delayed hypersensitivity by depletion of suppressor T cells with cyclophosphamide in mice. Nature 1976, 262:77-78.

57. Rollinghoff M, Starzinski-Powitz A, Pfizenmaier K, Wagner H: Cyclophosphamide-sensitive $\mathrm{T}$ lymphocytes suppress the in vivo generation of antigen-specific cytotoxic T lymphocytes. J Exp Med 1977, 145:455-459.

58. Asherson GL, Ptak W: Contact and delayed hypersensitivity in the mouse. I. Active sensitization and passive transfer. Immunology 1968, 15:405-416.

59. Maguire JRHC, Ettore VL: Enhancement of dinitrochlorobenzene (DNCB) contact sensitization by cyclophosphamide in the guinea pig. I Invest Dermatol 1967, 48:39-43.

60. Sullivan S, Bergstresser PR, Streilein JW: Analysis of dose response of trinitrochlorobenzene contact hypersensitivity induction in mice: pretreatment with cyclophosphamide reveals an optimal sensitizing dose. J Invest Dermatol 1990, 94:711-716.

61. Beyer M, Kochanek M, Darabi K, Popov A, Jensen M, Endl E, Knolle PA, Thomas RK, von Bergwelt-Baildon M, Debey S, Hallek M, Schultze JL: Reduced frequencies and suppressive function of CD4+CD25hi regulatory $T$ cells in patients with chronic lymphocytic leukemia after therapy with fludarabine. Blood 2005, 106:2018-2025.

62. Lutsiak ME, Semnani RT, De PR, Kashmiri SV, Schlom J, Sabzevari H: Inhibition of $\mathrm{CD} 4(+) 25+\mathrm{T}$ regulatory cell function implicated in enhanced immune response by low-dose cyclophosphamide. Blood 2005, 105:2862-2868

63. Ikezawa Y, Nakazawa M, Tamura C, Takahashi K, Minami M, Ikezawa Z: Cyclophosphamide decreases the number, percentage and the function of CD25+ CD4+ regulatory T cells, which suppress induction of contact hypersensitivity. J Dermatol Sci 2005, 39:105-112.

64. Ghiringhelli F, Larmonier N, Schmitt E, Parcellier A, Cathelin D, Garrido C, Chauffert B, Solary E, Bonnotte B, Martin F: CD4+CD25+ regulatory T cells suppress tumor immunity but are sensitive to cyclophosphamide which allows immunotherapy of established tumors to be curative. Eur J Immunol 2004, 34:336-344.

65. Ercolini AM, Ladle BH, Manning EA, Pfannenenstiel LW, Armstrong TD, Machiels JPH, Bieler JG, Emens LA, Reilly T, Jaffee EM: Recruitment of latent pools of high-avidity $\mathrm{CD} 8^{+} \mathrm{T}$ cells to the antitumor immune response. J Exp Med 2007, 201:1591-1602.

66. Proietti E, Greco G, Garrone B, Baccarini S, Mauri C, Venditti M, Carlei D, Belardelli F: Importance of cyclophosphamide-induced bystander effect on T cells for a successful tumor eradication in response to adoptive immunotherapy in mice. J Clin Invest 1998, 101:429-441.

doi:10.1186/1471-2172-11-54

Cite this article as: Miller et al:: Phenotype, functions and fate of adoptively transferred tumor draining lymphocytes activated ex vivo in mice with an aggressive weakly immunogenic mammary carcinoma. BMC Immunology 2010 11:54.

\section{Submit your next manuscript to BioMed Central and take full advantage of:}

- Convenient online submission

- Thorough peer review

- No space constraints or color figure charges

- Immediate publication on acceptance

- Inclusion in PubMed, CAS, Scopus and Google Scholar

- Research which is freely available for redistribution

Submit your manuscript at www.biomedcentral.com/submit
C Biomed Central 